\title{
Tension Between Shareholder Primacy and (QUASI) Monopoly: A ThEORETICAL ANALYSIS OF CONTROLling SHAREHOLDER ECONOMIES AND CHINA
}

\author{
Sang Yop Kang ${ }^{12}$
}

\begin{abstract}
Professor Mark Roe explained that the shareholder wealth maximization norm ("the norm") is not appropriate for a country with a (quasi) monopoly, because the norm encourages managers to maximize monopoly rents to the detriment of the national economy. This Article provides new findings and counter-intuitive arguments on the tension created by the norm and (quasi) monopoly, by exploring three key corporate governance concepts that Roe did not examine-(1) "controlling minority structure" (CMS), where dominant shareholders hold a fractional ownership in their controlled-corporations, (2) "tunneling" (i.e., the transfer of corporate wealth to controlling shareholders), and (3) Chinese state-owned enterprises (SOEs).

First, given (quasi) monopoly, this Article considers the impact of CMS. CMS controllers, due to their fractional economic interests (e.g., $5 \%$ ownership), do not have a strong incentive to vigorously follow the norm. When the norm is not actively sought, public shareholders lose the opportunity to gain the maximum monopoly profits. A positive byproduct,

\footnotetext{
${ }^{1}$ Associate Professor, Peking University (School of Transnational Law); J.S.D. (Doctor of the Science of Law) at Columbia University, School of Law; Attorney at Law; CFA (Chartered Financial Analyst)

${ }^{2}$ I thank Professors Jesse Fried at Harvard Law School, Marcus Cole at Stanford Law School, Clayton Gillette at NYU Law School, Richard Brooks, Merritt Fox, Jeffrey Gordon, and Curtis Milhaupt at Columbia Law School, and Wei Cen, Yan Feng, Daeyong Lee, and Young Joon Park at Peking University HSBC Business School, for discussions, comments, and constructive criticism. I also thank Dean Philip McConnaughay, Vice Dean Stephen Yandle, and Professor Francis Snyder at Peking University School of Transnational Law, for their support, advice, and suggestions. I presented this Article in a faculty seminar at Peking University School of Transnational Law, in a conference at the Korean Securities Law Association, and in another conference at the Korean Law and Economics Association. My thanks go to discussants and participants of my presentations. In addition, I thank Chancellor Wen Hai at Peking University Shenzhen Campus, Vice Chancellor Jeffrey Lehman at NYU Shanghai, and my colleagues (particularly Toomey Colleen and Chen Song) at Peking University School of Transnational Law, for their advice and moral support. I also thank Editor-in-Chief Anthony Gin and other editors at the University of Pennsylvania East Asia Law Review for their comments. Last but not least, I thank my wife, parents, parents-in-law, and brother, for endless support for me.
} 
however, is that national welfare is improved, since non-maximized monopoly profits do not hurt society and consumers to the fullest extent.

Second, given CMS and (quasi) monopoly, this Article analyzes the impact of tunneling. Since tunneling provides more cash flowsincluding illicit cash flows-to CMS controllers, it strengthens their incentive to maximize shareholder wealth. The direct effect of tunneling to public shareholders is, by definition, negative. Counter-intuitively, however, tunneling is indirectly beneficial - to some extent - to public shareholders, due to CMS controllers' reinforced incentive to increase profits. Thus, the net effect of tunneling on public shareholders is mixed. In regard to social welfare in (quasi) monopoly CMS, tunneling has a negative effect because it encourages CMS controllers to pursue monopoly rents in a more aggressive manner.

Third, this Article calls into question the effectiveness of the norm in a context of Chinese SOEs that do their business in domestic markets. Formally, the controlling shareholder of Chinese SOEs is the party-state. The party-state is, however, an agent of its citizens, who are the "ultimate shareholders" (and consumers). Given the (quasi) monopoly held by SOEs in China, the norm will encourage SOE managers to set a monopoly-profit maximizing price in domestic markets. Such pricing is beneficial to the citizens of China as the "ultimate shareholders" when the government holds a high percentage of ownership in an SOE. However, the pricing damages the citizens of China as consumers. Under certain circumstances, the combined effect of the norm on the "ultimate shareholders"-i.e., the citizens of China-could be a net loss if a significant amount of welfare in society disappears as dead-weight loss (DWL) in the national economy. 


\section{TABLE OF CONTENTS}

I. INTRODUCTION 131

II. TENSION BETWEEN MONOPOLY AND SHAREHOLDER 137 WEALTH MAXIMIZATION

A. Shareholder Wealth Maximization 137

1. Shareholder Primacy Norm in the United States 137

2. Shareholder Primacy Norm Outside the United 139 States

B (Quasi) Monopoly 141

1. Maximizing Monopoly Profits, Consumer Surplus, 141 Deadweight Loss, and Welfare of Society

2. Other Considerations 143

C. Tension between (Quasi) Monopoly and Shareholder 145

Wealth Maximization

D. Factors Uncovered by Roe 146

III. CONTROLling MinORITY STRUCTURE: (QUASI) 147

MONOPOLY, TUNNELING, AND SHAREHOLDER WEALTH

MAXIMIZATION

A. Controlling Minority Structure and Shareholder Wealth 148

Maximization

1. CMS Controller's Low Level of Economic Interests 148

2. Renunciation of Monopoly Profit Maximization: 150

Investors' Loss and Consumers' Benefit

3. Controller's Collective Action Problem in 152

Controlling Minority Structure

B. Deviation from Shareholder Wealth Maximization 153

1. CMS Controller's Size Preference 153

2. Controlling Shareholder's Personal Creed 155

C. Tunneling and (Quasi) Monopoly Profits 158

1. Tunneling of Substantially All of Corporate Assets 158 (e.g. Tunneling of Additional 85\%)

2. Small-Scale Tunneling (e.g., Tunneling of 159 Additional 3\%)

3. Significant (But Not Substantially All) Level of 161 Tunneling (e.g. Tunneling of Additional 25\%)

4. Comparison of All Scenarios 162

D. Summary and Other Considerations 163

IV. STATE-OWNED ENTERPRISES IN CHINA: (QUASI) 165

MONOPOLY AND SHAREHOLDER WEALTH

MAXIMIZATION

V. CONCLUDING REMARKS 169 


\section{INTRODUCTION}

Industrial organization and corporate governance are two significant topics when corporations pursue business goals, make strategic decisions, and deal with internal affairs. Academics - both economists and legal scholars - and policy-makers tend to treat these two fields independently except in a few cases like mergers and acquisitions (M\&A). This treatment simultaneously brings issues associated with monopoly regulation and investor protection.

Generally, (quasi) monopoly-monopoly with the sole supplier, ${ }^{3}$ and oligopoly, where a small number of market players wield a high level of price-setting power ${ }^{4}$-is deemed detrimental to society. Most jurisdictions impose regulations on (quasi) monopoly via antitrust laws, competition laws, and laws against large business entities. ${ }^{5}$ One primary rationale for economics to regulate imperfect competition in a market is that a (quasi) monopolist charges a higher price, while supplying a smaller quantity of a good or service than it would in a competitive market. This action transfers some of the economic surplus from consumers to the monopolist. ${ }^{6}$ In addition, "monopoly produces a net loss for society:"7 namely, a deadweight loss (DWL). Aside from this efficiency loss, a variety of fairness problems will emerge and cause many socio-political controversies. $^{8}$

Meanwhile, mainstream corporate governance scholarship, as exemplified by Dodge v. Ford Motor Co., articulates that the primary goal

\footnotetext{
${ }^{3}$ Robert B. CoOter Jr. \& ThOmas Ulen, LAw And ECONOMics 29 (Int'l ed., 6th ed. 2014) ("In a monopoly there is only one supplier; so, that firm and the industry are identical."). Some scholars, practitioners, and policy-makers defend certain patterns and types of monopolies, such as natural monopolies and monopolies that enhance innovation. See, e.g., Robert S. Pindyck \& DANiel L. Rubinfeld, MicroeConomics 388 (Global ed., 8th ed. 2015) (explaining the concept of natural monopoly). Such discussions on monopoly, though important, are beyond the scope of this Article. For more explanation of economies of scale and a natural monopoly, see infra Part II.B.2.

${ }^{4}$ In general, oligopoly is defined as "a market structure in which a small number of interdependent firms compete.” R. Glenn HubBard \& ANTHONy PATRick O'Brien, MicROECONOMics 432 (3rd. ed. 2010). In this Article, oligopoly is narrowly defined as a market, where a few market players exercise dominant market power in terms of setting a price and/or the level of quantity. If a small number of suppliers fiercely compete in a market without dominant market power, such a market structure does not constitute oligopoly in this Article. In other words, when defining oligopoly, this Article focuses on individual corporations' market power rather than simply the number of corporations in a specific market. See infra Part II.B.

${ }^{5}$ For instance, China promulgated the Anti-Monopoly Law in 2007, taking effect in 2008. Xiaoye Wang, Highlights of China's New Anti-Monopoly Law, 75 ANTITRUst L.J. 133, 133 n.3 (2008).

${ }^{6}$ Paul Krugman \& Robin Wells, Microeconomics 371 (2nd ed. 2009).

${ }^{7}$ Id.

${ }^{8}$ See infra Part II.B.1.
} 
of a corporation is to maximize shareholder wealth, ${ }^{9}$ which is usually expressed as share price. This view is also supported by Nobel laureate, Milton Friedman, in his famous essay The Social Responsibility of Business Is to Increase Its Profits. ${ }^{10}$ As the world economy has integrated, shareholder wealth maximization-in tandem with the shareholder primacy norm - has grown as an influential international standard. ${ }^{11}$

However, in The Shareholder Wealth Maximization Norm and Industrial Organization, Professor Mark Roe at Harvard Law School called into question the fundamental validity of shareholder primacy. "In nations where product markets are not strongly competitive, a strong shareholder primacy norm fits less comfortably with national wealth maximization than elsewhere because, where competition is weak, shareholder primacy induces managers to cut production and raise price more than they otherwise would." 12 (emphasis added). By analyzing potentially conflicting features of shareholder primacy in a given industrial organization, Roe pioneered uncharted territory in corporate governance. Perhaps, while the shareholder wealth maximization norm is a better standard for the United States, where markets are relatively more competitive, it might not be "the" global standard, particularly in developing countries with an imperfectly competitive market tainted by monopolistic features.

Regarding the tension between shareholder primacy and (quasi) monopoly, this Article examines three key factors that were not covered in Roe's insightful research: (1) "controlling minority structure" (CMS) (i.e., when dominant shareholders hold a small percentage of ownership) $;^{13}(2)$

\footnotetext{
${ }^{9}$ Dodge v. Ford Motor Co., 170 N.W. 668, 684 (Mich. 1919).

${ }^{10}$ Milton Friedman, The Social Responsibility of Business Is to Increase Its Profits, THE N.Y. Times Mag. Sep. 13, 1970, at 33. But see Jeffrey N. Gordon, The Rise of Independent Directors in the United States: Of Shareholder Value and Stock Market Prices, 59 Stan. L. REv. 1465, 1520 (2007) ("Milton Friedman's 1970 essay, The Social Responsibility of Business Is to Increase Its Profits, was a scandale because of its unvarnished emphasis on the shareholder value as virtually the sole criterion by which corporate performance should be judged. This view seemed far out of the mainstream.").

11 Some corporate law scholars explain that the concept of "shareholder wealth maximization" is a subset of the broadly defined concept of "shareholder primacy." See, e.g., Stephen M. Bainbridge, Director v. Shareholder Primacy in the Convergence Debate, 16 TRANSNAT'L LAW. 45, 45-46 (2002) (“The term shareholder primacy typically connotes two distinct principles: (1) [t] he shareholder wealth maximization norm . . . [and] (2) [t]he principle of ultimate shareholder control."). In this Article, however, the term "shareholder primacy" is narrowly defined, so that it is used interchangeably with "shareholder wealth maximization" (thus "shareholder primacy" is not related to the concept of the "principle of ultimate shareholder control").

${ }^{12}$ Mark J. Roe, The Shareholder Wealth Maximization Norm and Industrial Organization, 149 U. PA. L. REV. 2063, 2063 (2001).

${ }^{13}$ In CMS, for example, a controlling shareholder holding a $5 \%$ economic interest in a corporation can wield $51 \%$ of the voting rights. See generally, Lucian A. Bebchuk et al., Stock Pyramids, Cross-Ownership, and Dual Class Equity: The Mechanisms and Agency
} 
"tunneling" (i.e., wealth transfer from a corporation to its controlling shareholder); ${ }^{14}$ and (3) state-owned enterprises (SOEs) in China. Traditionally, policy-makers and corporate governance scholars have criticized institutional features in emerging markets such as CMS and tunneling. Also, Chinese SOEs have been considered highly inefficient due to their low profitability. ${ }^{15}$ In the analytical framework of shareholder wealth maximization and (quasi) monopoly, examining these three factors provides new implications on the interplay between corporate governance and industrial organization.

Recognizing the significance and complicated functions of CMS, tunneling, and Chinese SOEs, this Article explores further research questions: (1) Given (quasi) monopoly, how does CMS affect shareholder wealth maximization, investor protection, and social welfare?; ${ }^{16}(2)$ Given (quasi) monopoly and CMS, how does tunneling affect shareholder wealth maximization, investor protection, and social welfare?: ${ }^{17}$ and (3) Given the (quasi) monopolistic market power of Chinese SOEs, is there a chance that the shareholder wealth maximization norm will actually lower benefits to the (ultimate) shareholders of Chinese SOEs? ${ }^{18}$ To answer these questions, this Article provides new novel ideas and findings, some of which are counter-intuitive and contrary to the belief of extant corporate governance scholarship.

In a country with (quasi) monopoly, three outcomes will arise when a controller's percentage of ownership is substantially low, ceteris paribus (note that tunneling is not considered yet). ${ }^{19}$ First, the CMS

Costs of Separating Control from Cash-Flow Rights, in CONCENTRATED CORPORATE OWNERSHIP 295 (Randall K. Morck ed., 2000), available at http://www.nber.org/chapters/c9013.pdf (explaining CMS, voting leverage devices, and agency problems in CMS); see also, infra Part III.A.1 (providing a further explanation of CMS). Due to its distortive features in shareholder voting, CMS is related to many corporate governance issues such as agency problems, investor protection, and takeover defenses. See, e.g., Sang Yop Kang, Transplanting a Poison Pill to Controlling Shareholder Regimes-Why It Is So Difficult, 33 Nw. J. INT'L L. \& Bus. 619, 641-42 (2013) (describing CMS as an "internal defensive device" in a takeover situation).

${ }^{14}$ See generally, Simeon Djankov et al., The Law and Economics of Self-Dealing, 88 J. Fin. ECON. 430 (2008) (discussing corporate governance issues related to investor expropriation); Simon Johnson et al., Tunneling, 90 AM. ECON. REv. 22 (2000) (explaining the concept of tunneling).

${ }^{15}$ See, e.g., Fixing China Inc: Reform of State Companies Is Back on the Agenda, THE ECONOMIST, (Aug. 30, 2014), http://www.economist.com/news/china/21614240-reformstate-companies-back-agenda-fixing-china-inc ("Profitability of state companies has fallen, even as private firms have grown in strength. SOE returns are now about half those of their non-state peers.").

${ }^{16}$ For a further analysis of this question, see infra Part III.A and B.

${ }^{17}$ For a further analysis of this question, see infra Part III.C.

${ }^{18}$ For a further analysis of this question, see infra Part IV.

${ }^{19}$ See infra Part III.A and B (explaining potential outcomes of the CMS controllers' weak incentive to follow the shareholder wealth maximization norm). 
controller will have a weak incentive to strictly follow the profit maximization norm, since economic interests between a controller and the monopolist corporation are less aligned. Second, as a result, public investors' economic interests are likely to be damaged, since deviation from profit maximization lowers the price and profits in monopoly. Third, however, it is likely that the total efficiency of an economy, as well as consumer surplus, will be enhanced as the controller deviates from monopoly profit maximization. Note that in (quasi) monopoly shareholder wealth maximization is defined as monopoly rent maximization. Essentially, in terms of the level of welfare, the "square of a bad" (or "Bad") - the situation where a bad ownership structure of CMS and a bad industrial organization of (quasi) monopoly are combined $^{20}$-is socially desirable to some extent. ${ }^{21}$ CMS is also attractive to controlling family shareholders in China due to the feature of utilizing other people's money. Since markets in China are less competitive, the foregoing discussion-based on the combination of CMS and (quasi) monopoly - provides similar implications in the Chinese context.

When a CMS controller does not actively pursue monopoly profit maximization, all shareholders including the controller, bear the "opportunity cost" of losing monopoly profits that could have belonged to the shareholders. By the definition of CMS, the controller's opportunity cost is fractional. Thus, when a CMS controller finds it personally more desirable to not seek shareholder wealth maximization, the controller is willing to assume this fractional opportunity cost. For instance, by supplying more quantity of a good or service, a CMS controller can enlarge the size of a monopoly corporation. ${ }^{22}$ The controller will lose some monopoly profits on a pro-rata basis in the form of an opportunity cost. On the other hand, the controller may absorb benefits from the enlargement almost solely for himself or herself. In politics as well as in business, the size of a business often reflects the power of the controller. Alternatively, a CMS controller sometimes imposes personal philosophy onto corporate policy. To illustrate, Jack Ma pledged that the goal of Alibaba was to make customers and employees better off, ${ }^{23}$ which is reminiscent of Henry Ford's philanthropy in Dodge. In the case of a CMS, the CMS controllers are the only ones psychologically compensated when their own belief is realized in the corporation's policy while all shareholders - including the CMS controllers - bear the opportunity cost.

\footnotetext{
${ }^{20}$ See infra Part III.A.2.

${ }^{21}$ Despite the positive effects of the "square of a bad," however, other problems of (quasi) monopoly and CMS may persist. See infra Part III.D.

${ }^{22}$ See, e.g., Henry Hansmann \& Reinier Kraakman, The End of History for Corporate Law, 89 GEO. L.J. 439, 461 (2000) (observing that controlling shareholders pursue "nonpecuniary returns," particularly in Europe).

${ }^{23}$ See infra Part III.B.2 (explaining Jack Ma's CMS and his policy of "customer first, employees second, shareholders third").
} 
In addition, their reputation - rather than that of the entire shareholdersis enhanced, resulting in benefits to their future career.

Now, consider the effects of a CMS controller's tunneling, when a jurisdiction's market structures are based on (quasi) monopoly and CMS. This situation is described as the "cube of a bad" (or "Bad"), since another bad feature (i.e., tunneling) is added on top of the "square of a bad." ${ }^{24}$ In this situation, three outcomes will arise as the level of tunneling is higher, ceteris paribus. First, ironically, a CMS controller will have a stronger incentive to pursue the profit maximization norm. This is because the controller's economic interests in a corporation are strengthened through additional pecuniary benefits from tunneling. Second, tunneling is, by definition, detrimental to public shareholders. ${ }^{25}$ On the other hand, however, due to the first outcome, tunneling will becounter-intuitively-beneficial to public shareholders at least to some extent, since shareholder wealth maximization will be induced by tunneling. ${ }^{26}$ As a result, the net effect of tunneling on the welfare of public investors will depend on the relative size of the two opposing effects. ${ }^{27}$ However, extreme tunneling will take away public investors' confidence in a corporation and, eventually, most of them will not invest in the next stage. ${ }^{28}$ Third, the level of consumer surplus and national welfare will deteriorate as a CMS controller's strengthened incentive to follow shareholder wealth maximization increases monopoly profits and generates larger DWL. Since the quality of corporate governance in China is still low, the aforementioned three outcomes-generated from

\footnotetext{
${ }^{24}$ For the further analysis of the "cube of a bad" (or Bad ${ }^{3}$ ), see infra Part III.C (explaining potential outcomes of tunneling in (quasi) monopoly CMS, with respect to the shareholder wealth maximization norm).

${ }^{25}$ See Djankov et al., supra note 14, at 430 (explaining "the problem of investor expropriation, sometimes also referred to as self-dealing or tunneling"); Johnson et al., supra note 14, at 22 (describing tunneling as "the expropriation of minority shareholders").

${ }^{26}$ In this sense, the logic is also connected to an argument that public shareholders are not "unilateral victims," since they participate in profit sharing with a controlling shareholder when surplus is transferred from consumers to a corporation in an imperfect competitive market. See Sang Yop Kang, Re-envisioning the Controlling Shareholder Regime: Why Controlling Shareholders and Minority Shareholders Often Embrace, 16 U. PA. J. Bus. L. 843, 893-94 (2014) (discussing how minority shareholders may benefit when a controller "loots" other stakeholders).

${ }^{27}$ Note that I do not argue that the net effect of tunneling on public shareholders is positive. What I explain is the possibility that public shareholders could-indirectly and inadvertently-benefit from tunneling to some extent, which has been largely ignored in discussing corporate governance issues.

${ }^{28}$ Accordingly, a CMS controller, if he or she wishes to be a repeat player, would not choose an over-reaching level of tunneling. See generally Sang Yop Kang, "Generous Thieves": The Puzzle of Controlling Shareholder Arrangements in Bad-Law Jurisdictions, SOC. SCI. RESEARCH NETWORK (2013), http://ssrn.com/abstract_id=2305645 (explaining that a controlling shareholder tends to generously expropriate other investors when she/he is a repeat player).
} 
tunneling, CMS, and (quasi) monopoly-will be likely to apply to controlling family shareholders in China.

Next, in the context of shareholder primacy, let us theoretically examine Chinese SOEs, particularly those who are (quasi) monopolies in the domestic market (or a local market). ${ }^{29}$ Two implications are noteworthy. ${ }^{30}$ First, as opposed to common sense, the shareholder wealth maximization norm-if implemented without reforming the established (quasi) monopoly of SOEs - could be counterproductive to China. This is because the norm will encourage the managers of SOEs to reduce the quantity of a good or service and to charge a higher price in China. These actions will result in more monopoly profits, but at the loss of national welfare. $^{31}$

Second, in Chinese SOEs supplying goods or services predominantly for domestic consumers, it is possible that the shareholder wealth maximization norm would also be harmful to the (ultimate) shareholders. Formally, the controlling shareholder of Chinese SOEs is the party-state (or the government). However, the state is a primary agent of the citizens of China, who are indeed the "ultimate shareholders." 32 Thus, at least in theory, the citizens of China collectively (and indirectly) own an SOE, particularly when the party-state holds 100\% (or a high percentage) of ownership. Meanwhile, the citizens of China are, roughly speaking, the same as the consumer group of SOEs doing business in the domestic market. At a glance, it seems that a corporate policy based on the shareholder wealth maximization norm will enhance the level of profits in favor of the "ultimate shareholders." However, these profits are transferred from the consumer group, which is actually the group of "ultimate shareholders." Thus, the transfer takes place simply from the right pocket to the left pocket. A more systemic problem is that, during the course of the wealth transfer, a large amount of welfare will disappear

\footnotetext{
${ }^{29}$ See infra Part IV (explaining negative potential outcomes that the shareholder wealth maximization norm brings in Chinese SOEs).

${ }^{30}$ These implications might also apply to similarly situated SOEs in other countries. Note, however, that these implications are more meaningful to China, since China is officially a communist economy where SOEs play a key role. See infra Part IV.

${ }^{31}$ For the same reasons, it is possible that there will be similar unintended (undesirable) consequences if a stock option arrangement - designed to align the managers' incentive with shareholder wealth - is widely adopted in these SOEs. Since a stock option is a vehicle that incentivizes SOE managers to attempt to maximize monopoly rents, it is possible in China that a stock option can generate a great deal of DWL and hurt domestic consumers, the citizens of China, who are "ultimate shareholders" of SOEs. For the concept of "ultimate shareholders" of SOEs, see infra note 32 and accompanying text. Currently, I am conducting an independent research project to explore these issues related to stock options in China.

${ }^{32}$ For a similar view, see Donald C. Clarke, Corporate Governance in China: An Overview, 14 China ECON. Rev. 494, 499 (describing the citizens of China as "the ultimate theoretical principal in the case of state ownership").
} 
in the form of DWL. Consequently, when shareholder wealth maximization applies to Chinese SOEs playing in industries for domestic demand, the net worth of "ultimate shareholders" will be lowered.

This Article is organized as follows. Part II introduces the concepts of (quasi) monopoly and shareholder wealth maximization, Roe's insight into those concepts, and the three factors (i.e., CMS, tunneling, and Chinese SOEs) that Roe did not emphasize. Part III explores intricately inter-related issues - such as CMS, tunneling, a controller's weak incentive to follow profit maximization, investor protection, and social welfare-in the context of the tension between monopoly and shareholder primacy. Part IV covers separate topics from Part III. ${ }^{33}$ Regarding the tension, Part IV explores the relationship in China among SOEs, the government, and the citizens of China. Part V summarizes and concludes.

\section{TENSION BETWEEN MONOPOLY AND SHAREHOLDER WEALTH MAXIMIZATION}

This Part begins with theories on shareholder wealth maximization and monopoly. Subsequently, it covers both the insight and missing factors from Roe's article. A fundamental tension between (quasi) monopoly and shareholder wealth maximization will be emphasized.

\section{A. Shareholder Wealth Maximization}

According to U.S. corporate governance scholarship, the primary aim of a corporation is to maximize shareholder value. ${ }^{34}$ Basically, shareholder wealth maximization is rooted in the fundamental belief that corporate agents' fiduciary duties should be discharged for shareholders as explained by Aronson v. Lewis. ${ }^{35}$

\section{Shareholder Primacy Norm in the United States}

In the United States, the shareholder wealth maximization principle was pronounced in the famous case of Dodge v. Ford Motor Company. ${ }^{36}$ Henry Ford, the majority shareholder of Ford Motor

\footnotetext{
${ }^{33}$ Part IV does not explore issues related to CMS and tunneling.

${ }^{34}$ See, e.g., Bainbridge, supra note 11, at 45 ("This principle [of shareholder wealth maximization] is well-established in U.S. corporate law.").

${ }^{35}$ Aronson v. Lewis, 473 A.2d 805 (Del. 1984) (citing Loft, Inc. v. Guth, 2 A.2d 225 (Del. Ch. 1938)).

${ }^{36}$ Dodge v. Ford Motor Co., 170 N.W. 668 (Mich. 1919). Dodge is often considered the leading case on shareholder primacy in the United States. See, e.g., Stephen M. Bainbridge, Director Primacy: The Means and Ends of Corporate Governance, 97 Nw. U. L. REv. 547, 574-75 (2002) (explaining Dodge in the context of shareholder wealth maximization).
} 
Company - a very lucrative business - reinvested earnings, lowered prices for consumers, and enhanced working conditions for employees. ${ }^{37}$ The Dodge brothers, minority shareholders of Ford Motor Company, brought suit and demanded that the company pay more dividends. ${ }^{38}$ Ford defended his policy of withholding profits inside the company, based on his belief of the corporation as a public good. For instance, he testified that his "ambition" was to make employees better off. ${ }^{39}$ Ford's altruism for consumers was also pointed out in the case: "[Mr. Ford] thinks the Ford Motor Company ... . has had too large profits, and that, although large profits might be still earned, a sharing of them with the public, by reducing the price of the output of the company, ought to be undertaken." 40 Emphasizing that the primary goal of a corporation is to make profits for stockholders, ${ }^{41}$ the Court articulated that " $[t]$ he discretion of directors is to be exercised in the choice of means to attain that end, and does not extend to a change in the end itself, to the reduction of profits, or to the non[-]distribution of profits among stockholders in order to devote them to other purposes." ${ }^{2}$ The Court ruled in favor of the Dodge brothers.

The spirit of shareholder primacy is also well preserved in the current case law in Delaware, the center of modern United States corporate law. ${ }^{43}$ For instance, Judge Leo Strine explained that "our corporate law (and that of most of our nation) expects that the directors of a solvent firm will cause the firm to undertake economic activities that maximize the value of the firm's cash flows primarily for the benefit of the residual risk-bearers, the owners of the firm's equity capital." 44 (emphasis added). Traditionally, shareholders are considered the "owners" of a corporation. ${ }^{45}$ If so, the idea of maximizing net benefits for a corporation's owners is easily justified. Even if shareholders are not

Some scholars are, however, critical of the implications of Dodge. See, e.g., Lynn A. Stout, Why We Should Stop Teaching Dodge v. Ford, 3 VA. L. \& Bus. Rev. 163 (2008).

${ }^{37}$ See Bainbridge, supra note 36 , at 574-75.

${ }^{38}$ See, e.g., Stout, supra note 36, at 164-65 (providing a further explanation of the case); see also Bainbridge, supra note 36 , at 574-75.

${ }^{39}$ Dodge, 170 N.W. at 683.

${ }^{40} I d$. at $683-84$.

${ }^{41} I d$. at 684 ("A business corporation is organized and carried on primarily for the profit of the stockholders.").

${ }^{42} I d$.

${ }^{43}$ See, e.g., Jonathan R. Macey \& Geoffrey P. Miller, Toward an Interest-Group Theory of Delaware Corporate Law, 65 TEX. L. REV. 469, 490 (explaining how the center of the modern U.S. corporate law changed from New Jersey to Delaware).

${ }^{44}$ Production Resources Group, L.L.C. v. NCT Group, Inc. 863 A.2d 772, 787 (Del. Ch. 2004) (citing Roe, supra note 12).

${ }^{45}$ See, e.g., Shareholder Rights: Power to the Owners, THE EcONOMIST (Mar. 9, 2013), http://www.economist.com/news/leaders/21573121-activist-shareholders-are-right-mountbarricades-politicians-are-wrong-cap (explaining the notion of shareholders as owners of a company in a context of shareholder activism). 
precisely the "owners" of a corporation, ${ }^{46}$ the notion of shareholders as "residual claimants" buttresses the principle of shareholder wealth maximization. This theory posits that shareholder wealth maximization is optimal in a corporation, since other constituencies of a corporation (such as employees, suppliers, creditors, and even the government ${ }^{47}$ ) already receive their cash flows before the shareholders do. ${ }^{48}$ As a result, shareholder wealth maximization, as long as it is achieved in a proper manner with fair treatment and protection of other constituencies, ${ }^{49}$ improves Pareto efficiency without hurting the welfare of other constituencies. ${ }^{50}$

\section{Shareholder Primacy Norm Outside the United States}

Outside the United States, many jurisdictions have started to seriously consider the notion of shareholder protection. For instance, Korea has made a series of corporate law reforms since the Asian financial crisis in 1997. In general, the direction of these reforms has been consistent with the shareholder primacy norm. ${ }^{51}$ In Korea, shareholder derivative suits have been raised - though the frequency is less than that of the United States, (perhaps) the most active jurisdiction in the world-

\footnotetext{
${ }^{46}$ There are commentators who explain that shareholders are not owners of a corporation. See, e.g., Martin Lipton \& William Savitt, The Many Myths of Lucian Bebchuk, 93 VA. L. REV. 733, 754 (2007) (“Shareholders do not 'own' corporations. They own securitiesshares of stock - which entitle them to very limited electoral rights and the right to share in the financial returns produced by the corporation's business operations."); see also Bainbridge, supra note 36, at 551 (introducing a similar view).

${ }^{47}$ The government receives cash flows from a corporation in the form of corporate taxes, before shareholders receive cash flows such as dividends.

${ }^{48}$ Recall that shareholders are residual claimants of a corporation, but note that this argument can be weakened when other constituencies are not properly protected. See Production Resources Group, 863 A.2d at 787 (explaining shareholder wealth maximization based on the assumption that creditors are already protected by contractual agreements, the law of fraudulent conveyance, and federal bankruptcy law).

${ }^{49}$ See Roe, supra note 12, at 2065 ("In the long run, the argument goes, employees and other stakeholders are overall better off with fluid and efficient capital markets, managers need a simple metric to follow, and both wealth and, in the end, fairness are maximized by shareholders being the corporation's residual beneficiary, with the other claimants getting what they want via contract with the corporation.").

${ }^{50}$ As to the concept of Pareto efficiency, see PINDYCK \& RUBINFELD, supra note 3, at 598 ("In a Pareto efficient allocation of goods, no one can be made better off without making someone else worse off.").

${ }^{51}$ In addition to voluntary reforms inside Korea, such a significant alteration is partly due to external influence from the international community and creditor institutions. See, e.g., Hwa-Jin Kim, Living with the IMF: A New Approach to Corporate Governance and Regulation of Financial Institutions in Korea, 17 BERKELEY J. INT'L L. 61, 62 (1999) ("The process of reform was hastened by the foreign exchange crisis of 1997 and the consequential involvement of the international lending agencies such as the International Monetary Fund (IMF) and the World Bank in the restructuring of Korean industries.").
} 
since the first derivative suit case against the Korea First Bank in $1997 .{ }^{52}$ In China, reforms have strengthened protection for shareholders although it did not experience a major financial crisis comparable to the Asian financial crisis in 1997. For instance, the derivative suit system has gradually developed ${ }^{53}$ and the notion of independent directors has been emphasized in a significant manner. ${ }^{54}$

In addition, shareholder activism - such as hedge funds' aggressive investment and participation in the decision-making processes in corporations - in line with the shareholder wealth maximization norm is encouraged. ${ }^{55}$ To illustrate, a corporate governance dispute took place recently between Elliott Associates (hereinafter Elliott), a U.S. hedge fund, and Samsung Group, a large Korean corporate group in which the globally prestigious smart-phone and semi-conductor producer, Samsung Electronics, is an affiliated company. ${ }^{56}$ Samsung Group proceeded with a merger of Samsung C\&T by Cheil Industries, a de facto holding company of the group. Arguably, the main reason for the proposed merger was to strengthen the control of the current controlling shareholder of the Lee family, since Samsung C\&T was a large shareholder of the group's flagship company, Samsung Electronics. ${ }^{57}$ After it purchased $7.12 \%$ of

\footnotetext{
${ }^{52}$ See, e.g., Bernard Black et al., Shareholder Suits and Outside Director Liability: The Case of Korea, 10 J. KorEAn L. 325, 344-45 (2010) (explaining the 1997 Korea First Bank case, the first derivative suit in Korea).

${ }^{53}$ See Hui Huang, The Statutory Derivative Action in China: Critical Analysis and Recommendations for Reform, 4 BERKELEY BUS. L.J. 227, 229 (2007) (providing a further explanation of the derivative suit system in China); see also Hui Huang, Shareholder Derivative Litigation in China: Empirical Findings and Comparative Analysis, 27 B.F.L.R. 619, 622 (2012), available at http://ssrn.com/abstract_id=2140613. See Sang Yop Kang, Taking Voting Leverage and Anti-Director Rights More Seriously: A Critical Analysis of the Law and Finance Theory, (Peking University School of Transnational Law Research Paper No. 15-3, 2015) available at http://ssrn.com/abstract=2669420 (providing a brief comparison of derivative suit systems in the United States, China, and Korea).

${ }^{54}$ See, e.g., Ling Zhou, The Independent Director System and Its Legal Transplant into China, 6 J. Comp. L. 262, 263 (2011) ("The 'independent director' is a vivid example of legal transplant into China's post-Mao legal system.”).

${ }^{55}$ See, e.g., Alon Brav et al., Hedge Fund Activism, Corporate Governance, and Firm Performance, 63 J. FIN. 1729, 1729 (2008) (finding that "activist hedge funds in the United States propose strategic, operational, and financial remedies and attain success or partial success in two-thirds of the cases [from 2001 to 2006].").

${ }^{56}$ See Corporate Governance in South Korea: Reconstructing Samsung, THE ECONOMIST (July 11, 2015), http://www.economist.com/news/business/21657377-bid-merge-twogroups-companies-raises-wider-questions-reconstructing-samsung (explaining the planned mergers between Cheil Industries and Samsung C\&T); see also Elliott Turns up Heat on Samsung over Merger Bid, YONHOP News (June 18, 2015, 18:55), http://english.yonhapnews.co.kr/news/2015/06/18/0200000000AEN20150618001253320.h tml.

57 See Simon Mundy, Samsung's Founding Family Strengthens Grip on Group, THE FinANCIAL Times (July 17, 2015, 9:15 AM), http://www.ft.com/cms/s/0/0f7b9934-2c3f-
} 
Samsung C\&T's shares ${ }^{58}$ Elliott became the third largest shareholder of the company. Elliott contended that the proposed deal is "neither fair to nor in the best interests of Samsung C\&T's shareholders." 59 In response to this criticism, interestingly, Samsung Group also defended the deal based on the shareholder primacy norm, arguing that the merger will eventually create value for Samsung C\&T shareholders due to the synergy with Cheil Industries' business portfolio. ${ }^{60}$

The issue of which party's argument is more convincing - though it is important and intriguing in the corporate governance scholarship-is beyond the scope of this Article. ${ }^{61}$ What I emphasize here is that shareholder primacy and shareholder wealth maximization are standards that the arguments of both Elliott and Samsung Group are grounded upon. Indeed, in many countries outside the United States and the United Kingdom, shareholder primacy and shareholder wealth maximization are gradually accepted as the standard to measure the quality of corporate governance.

\section{B. (Quasi) Monopoly}

Let us set aside the issues of shareholder wealth maximization for a moment and consider (quasi) monopoly on a stand-alone basis. For the sake of simplicity, take an example of a product market of a good. According to microeconomics theory on producer behavior, a corporation - if it is economically rational and attempts to maximize profits-determines the level of output (hereinafter $Q m$ ), where the marginal revenue (hereinafter $M R$ ) - namely, the increased revenue from producing one more unit - is equal to the marginal cost (hereinafter $M C$ ) namely, the increased cost of producing one more unit. ${ }^{62}$

\section{Maximizing Monopoly Profits, Consumer Surplus, Deadweight Loss, and Social Welfare}

\footnotetext{
11e5-8613-e7aedbb7bdb7.html\#axzz3rgQ1du00 (discussing “Samsung C\&T's 4 percent stake in Samsung Electronics").

${ }^{58}$ Jungah Lee \& Rose Kim, Activist Investor Elliott Starts 'War' on Samsung's Lees, BLOOMBERG (June 5, 2015, 10:44 AM), http://www.bloomberg.com/news/articles/201506-03/elliott-says-cheil-takeover-of-samsung-c-t-undervalues-company-iaherbxb.

${ }^{59} I d$. A rumor spread that Samsung prepared the proposed merger as a way of sacrificing shareholder wealth, with the sole benefits going to the controlling family of the group. See The ECONOMIST, supra note 56.

${ }^{60} I d$.

${ }^{61} \mathrm{I}$ am currently conducting further research on this issue in an independent project.

${ }^{62}$ See PINDYCK \& RUBINFELD, supra note 3, at 292-93; see also COOTER \& ULEN, supra note 3 , at 27 ("the profit-maximizing output of the firm is shown at the point at which the marginal cost curve, labeled $M C$, and marginal revenue curve of the firm are equal.").
} 
This general principle of profit maximization (i.e., $M R=M C$ ) also applies to a monopoly corporation, when it rationally tries to maximize monopoly profits $^{63}$ (see the following Figure 1). At the point where $M R$ equals $M C$, the monopolist determines the amount of monopoly-profitmaximizing output $(\mathrm{Qm})$ and, based on a demand curve that consumers face, charges the monopoly-profit-maximizing price (hereinafter $\mathrm{Pm}$ ) ${ }^{64}$ $P m$ is higher than the price determined in a competitive market (hereinafter $P c) .{ }^{65}$ For this reason, it is generally explained that a monopolist has the price-setting capacity, while a supplier in a competitive market is merely a price-taker. ${ }^{66} \mathrm{Qm}$ is lower than the output level in a competitive market $(Q c):^{67}$ in response to a higher price in a monopoly, consumers reduce their consumption.

Although the combination of $P m$ and $Q m$ is optimal to the monopolist, it lowers the level of consumer surplus. Wealth transfers from the group of consumers to the monopolist (graphically, Rectangle A indicates the transfer in Figure 1). There are fairness issues in regard to this wealth transfer - though the issues are more like a socio-political agenda. For instance, "if consumers on average are poorer than producers (more precisely, than the owners of the producers), ${ }^{68}$ such a transfer will exacerbate the discrepancy between the poor and the wealthy. ${ }^{69}$ From an efficiency standpoint, this type of wealth transfer is also problematic, since DWL, a net loss in an economy, is created in the course of the transfer. Specifically, DWL can be divided into two parts: (1) surplus that consumers lose, since they reduce consumption at a higher monopoly

\footnotetext{
${ }^{63}$ PindyCK \& RUBINFELD, supra note 3, at 367-68 (explaining the output decision of a monopolist which tries to maximize profits).

${ }^{64}$ See infra Figure 1.

${ }^{65}$ PindYCK \& RUBINFELD, supra note 3, at 385 ("In a competitive market, price equals marginal cost. Monopoly power, on the other hand, implies that price exceeds marginal cost."). Mathematically, $P c=M C$ and $P m>M C$. Thus, $P m>P c$.

${ }^{66} I d$. at 288 (explaining that "firms in perfectly competitive markets are price takers"). But, note that it does not mean that a monopolist can set any price. Id. at 366. A monopoly company, if it tries to maximize profits, can set a price within the upper limit of $\mathrm{Pm}$. It can determine a price level, which is higher than $P m$. In that case, however, the level of profits will be lower than that at $P m$, since the effect from a higher price would be outweighed by the opposite effect from the reduced quantity that consumers would consume. See id. Meanwhile, $[P m-P c] / P c)$ is referred to as the Lerner Index. Roger D. BLAIR \& DAVID L. KASERMAN, ANTITRUST ECONOMICS 104 (2nd ed. 2009) (explaining the Lerner Index as "[t]he most commonly used measure of monopoly power"). In other words, when the difference between $P m$ and $P c$, if it is divided by $P c$, is large, a monopolist has strong market power.

${ }^{67}$ BLAIR \& KASERMAN, supra note 66 , at 37.

${ }^{68}$ RichaRd A. POSNER, ECONOMIC ANALYSIS OF LAW 285 (7th ed. 2007).

${ }^{69}$ This phenomenon also lowers the level of society's utility. Id. ("because of declining marginal utility of income, a dollar is worth more to the average consumer than to the average producer . . . even if there is no effect on output and therefore no deadweight loss.").
} 
price (Triangle $B$ in Figure 1) ${ }^{70}$ and (2) surplus that the monopolist loses, since at the higher monopoly price, the monopolist is not able to sell a certain quantity of goods (Triangle $C$ in Figure 1). ${ }^{71}$ As a result, the level of social welfare - the total sum of consumer surplus and producer surplus - in monopoly is lower than in a competitive market by DWL, namely Triangle $B$ plus Triangle $C^{72}$

\section{FIGURE 1: GRAPH OF MONOPOLY}

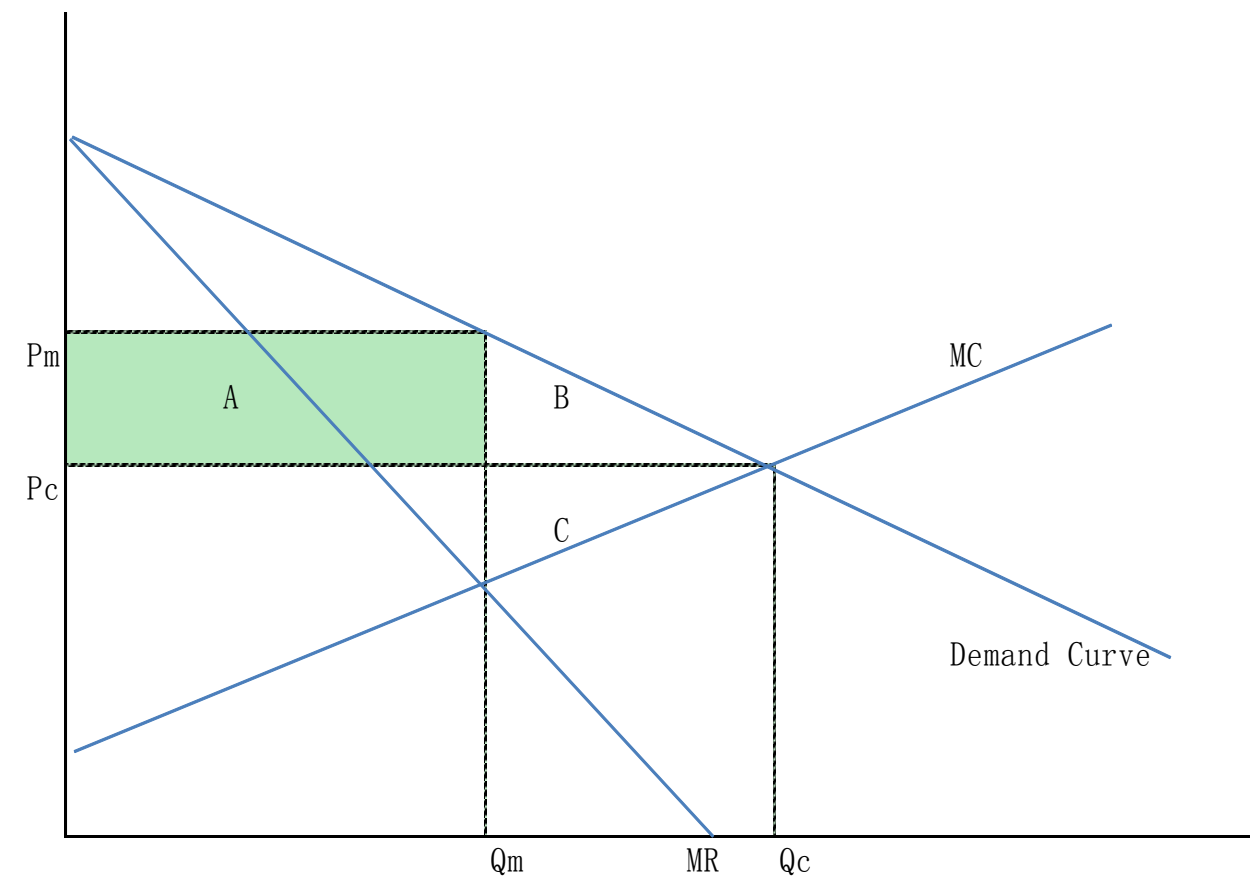

\section{Other Considerations}

A few points are worth noting further. First, certain patterns of monopoly - such as a monopoly based on economies of scale (or scope) ${ }^{73}$ or a monopoly that enhances innovation-could be efficient. ${ }^{74}$ For instance, economies of scale can generate a natural monopoly, "a firm that can produce the entire output of the market at a cost that is lower than

\footnotetext{
${ }^{70}$ See PINDYCK \& RUBINFELD, supra note 3 , at 386.

${ }^{71} \mathrm{Id}$.

${ }^{72} I d$.

${ }^{73}$ See COOTER \& UlEN, supra note 3, at 29 ("Economies of scale are a condition of production in which the greater the level of output, the lower the average cost of production.") (emphasis in the original text).

${ }^{74}$ See supra note 3 and accompanying text.
} 
what it would be if there were several firms."75 "[A natural monopoly] is more efficient to let it serve the entire market rather than have several firms compete." 76 However, this Article does not focus on analyzing such features. Second, oligopoly-when only a few producers exercise dominant market power-would generate similar welfare problems (e.g., DWL), although the price-setting power of oligopolistic companies is less than that of the monopolist. ${ }^{77}$ Table 1 summarizes the general contours of monopoly, oligopoly, and a competitive market.

Third, oligopoly - if it is defined by a number of existing competitors-is also the most common market structure in the United States. It can be said, however, that the structure of U.S. oligopolies-for example, the markets for automobiles or smart phones - are markedly different from the structure of oligopolies in other countries. The entry barriers of U.S. markets are low, so the U.S. product markets are quite open to domestic and foreign companies. Accordingly, the extent of competition - not only from existing producers, but also from potential competitors ready to enter the U.S. markets - is high. Thus, in the United States, the problem associated with exorbitant market power by a few oligopoly corporations is less serious. For these reasons, the narrowly defined oligopoly in this Article-where there are a few established market players and those players exercise dominant market power without worrying very much over potential competition ${ }^{78}$-is more likely to be found in less developed countries than in the United States.

Table 1: Price and Quantity of Industrial Organizations

Generally,

- $P m>P_{O}>P c$

- $Q m<Q o<Q c$

- $W m<W_{O}<W_{c}$

$P m$ : price that maximizes monopoly profits

$Q m$ : quantity that maximizes monopoly profits

$W m$ : social welfare under monopoly

$P o$ : price charged in an oligopoly market

\footnotetext{
${ }^{75}$ PINDYCK \& RUBINFELD, supra note 3 , at 388.

${ }^{76} \mathrm{Id}$.

${ }^{77}$ Under these circumstances, in general, an oligopoly price is higher than a competitive market price, but is lower than a monopoly price. Also, in general, the level of output available in oligopoly is higher than that in monopoly, but is lower than that in a competitive market. An oligopoly price is not always higher than a competitive market price, however, if producers in oligopoly face fierce price competition. However, this Article focuses only on oligopoly where established companies exercise significant market power. See supra note 4 and accompanying text.

${ }^{78}$ See supra note 4 and accompanying text.
} 
Qo: quantity produced in an oligopoly market

Wo: social welfare under oligopoly

$P c$ : price charged in a competitive market

Qc: quantity produced in a competitive market

$W c$ : social welfare under a competitive market

\section{Tension Between (Quasi) Monopoly and Shareholder Wealth Maximization}

Recently, corporate law scholars, economists, policy-makers, and judiciaries outside the United States have often emphasized legal reforms based on arguments in line with shareholder primacy. When such jurisdictions (particularly developing countries) import the AngloAmerican corporate governance ideology, an unconsidered potential risk is that the shareholder wealth maximization norm may be incompatible with the country's underlying legal and market infrastructures.

In this light, Roe's argument is of significance. In terms of social efficiency, Roe pointed out that shareholder primacy would create undesirable consequences. ${ }^{79}$ Since Roe compared the United States and Europe, his argument can be understood in the following way: in the United States where product markets were competitive, ${ }^{80}$ shareholder wealth maximization would be beneficial to the domestic economy, but in Europe where product markets were less competitive, it is possible that shareholder wealth maximization would not be beneficial to society. ${ }^{81}$ Roe's analysis can be further developed and applied to emerging countries, where (quasi) monopoly is a dominant market structure. It is noteworthy, however, that Roe pointed out a potentially negative effect of shareholder primacy on welfare at the national level. Roe did not refute that shareholder wealth maximization is beneficial to shareholders. In this light, an argument of this Article-explained in Part IV-is novel and intriguing: for Chinese SOEs that are wholly (or substantially) owned by the government and that have (quasi) monopolistic power in domestic markets, there is a high chance that the shareholder wealth maximization

\footnotetext{
${ }^{79}$ See Roe, supra note 12 , at 2063.

${ }^{80}$ In general, even a market with a small number of competitors in the United States is exposed to the high level of competition. See supra Part II.B.2.

${ }^{81}$ See Roe, supra note 12, at 2063; see also supra note 12. In regard to Roe's analysis, one may argue that as the European market has been further integrated, it is probable that the level of market competition in the United States and the Europe will be converged. The European market is, however, not fully integrated as one unified economy like the United States. The recent debate on possible exit of Greece and the United Kingdom from the Eurozone or the European Union ("Grexit" and "Brexit") is evidentiary.
} 
norm will bring negative impacts on the (ultimate) shareholders, not to mention on national welfare. ${ }^{82}$

The recent case of Korea Electricity Power Corporation (KEPCO), the monopoly supplier of electricity in Korea, provides a good example of the conflict between the shareholder primacy norm and (quasi) monopoly regulation. When determining a price, management of KEPCO discusses it with the Korean government, which considers the price of electricity as a factor of macro-economic policy in inflation and the general price level. Conventionally, the price of electricity has been set at a low level. Although KEPCO was discontent with the government's low pricing policy, the government's guidelines on pricing generally prevailed. In 2011, a group of minority shareholders brought a derivative suit against the then-CEO Ssang-Su Kim for damages of approximately 2.4 billion dollars, accusing the management of KEPCO of abandoning shareholder wealth by sticking to the government's policy. ${ }^{83}$ Eventually, the court opined that such a business practice-after consultation with the government, which was concerned about inflationary pressure-was lawful. ${ }^{84}$ Although Mr. Kim won, according to reports, he personally had to bear huge legal costs to defend this case. ${ }^{85}$ This story indicates that the tension between monopoly (or oligopoly) regulation and the shareholder primacy norm is not only a potential issue, but an issue that could be realized in corporate litigation. This case gives similar implications to China in the future, if shareholder primacy is aggressively accepted and a derivative suit system is further developed.

\section{Factors Uncovered by Roe}

\footnotetext{
${ }^{82}$ See infra Part IV.

${ }^{83}$ See, e.g., Sejin Jeong (정세진), Toeim 1 ju namatda, Hanjeon Kim Ssang-Su sajang 2 jo 8000 eok sonbaeso danghaetda (퇴임 1 주 남았다, 한전 김쌍수 사장 2 조 8000 억 손배소 당했다) [One Week from Retirement, KEPCO CEO Ssang-Su Kim Sued for Damages of 2.8 Trillion Won], Dong-A ILbO (Aug. 20, 2011, 03:00), http://news.donga.com/3/all/20110820/39667624/1. KEPCO minority shareholders also brought a related suit against the Korean government for its allegedly wrongful intervention when determining the price of electricity, but the government won. See, e.g., Sang-Hoon Jin (진상훈), Hanjeon soaekjuju, gookga sangdae 7 jowondae sonhaebaesangsosong paeso (한전 소액주주, 국가 상대 7 조원대 손해배상소송 패소) [KEPCO Minority Shareholders Lost the 7 Trillion-Won Case Against the Government], CHOSUN BIZ (Oct. 5, 2012, http://biz.chosun.com/site/data/html_dir/2012/10/05/2012100501200.html.

${ }^{84}$ See Jin, supra note 83

${ }^{85}$ It was expected that his legal expenses would be a few million dollars, which possibly would not be covered by the corporation. See Jeong, supra note 83.
} 
Roe's argument is insightful. Based on his seminal work, however, there are many important and timely issues that could have been explored further. For example, his analytical framework did not include CMS, where a controlling shareholder holds a minority economic interest in the controlled corporation. ${ }^{86}$ This seemingly odd ownership structure is, however, used in many jurisdictions. Voting leverage devices - such as stock pyramiding, dual-class equity structures, and cross shareholdingmake CMS available. ${ }^{87}$ Due to its peculiar feature of a disproportionate relation between cash flow rights and voting rights, CMS-when it is combined with (quasi) monopoly-potentially creates interesting phenomena in the context of shareholder wealth maximization. Part III explores the combined effects from CMS, a CMS controller's incentive, tunneling, (quasi) monopoly, and shareholder primacy.

Also, Roe's original research on shareholder primacy did not cover the Chinese economy. The dual-role of Chinese SOEs, as public entities as well as corporations, is a critical topic in the analysis of the tension between (quasi) monopoly and shareholder wealth maximization. Part IV provides a series of novel and counter-intuitive explanations regarding the situation in Chinese SOEs analyzing the impact of national welfare, consumers, and shareholders.

\section{CONTROLLING MinORITY STRUCTURE: (QUASI) MONOPOLY, TUNNELING, AND SHAREHOLDER WEALTH MAXIMIZATION}

This Part explores CMS economies in the context of (quasi) monopoly and shareholder primacy. Compared to the United States, the industrial organization of CMS-based economies (particularly developing countries) tends to be more monopolistic, with economic power concentrated in large business entities. ${ }^{88}$ As discussed, an economically rational monopoly "corporation" is assumed to make a decision in order to maximize monopoly profits. ${ }^{89}$ Note, however, that a corporation is a fictional person created by law. ${ }^{90}$ Although it is legally assumed that business decisions are made by a "corporation" (monopolist in this

\footnotetext{
${ }^{86} \mathrm{CMS}$ is one of the most significant factors in analyzing economies dominated by large corporate groups.

${ }^{87}$ See generally, Bebchuk et al., supra note 13.

${ }^{88}$ The United States has long been considered a representative free market economy, encouraging competition in society. See, e.g., Standard Oil Co v. FTC, 340 U.S. 231, 248 (1951) ("The heart of our national economic policy long has been faith in the value of competition.").

89 See PINDYCK \& RUBINFELD, supra note 63 and accompanying text.

${ }^{90}$ A similar issue, in different circumstances and for a different research question, was raised in another article. See Kang, supra note 26, at 863-66 (analyzing Gilson's riddles and the product market-based account).
} 
Article), decision-makers are, in reality, corporate insiders such as a controlling shareholder. ${ }^{91}$

\section{A. Controlling Minority Structure and Shareholder Wealth Maximization}

A CMS controller, by definition, has minority ownership in a corporation (e.g., 5\%), while the controller wields a majority of voting rights (e.g., 51\%). As explained below, a CMS controller has a weak incentive to choose the profit maximization point.

\section{CMS Controller's Low Level of Economic Interests}

CSM-based business organizations are found in the United States as well as in Asia and Europe. In 2014, in the four largest corporate groups in Korea, controlling shareholders and their families held, on average, $0.9 \%$ and $1.2 \%$ ownership respectively. ${ }^{92}$ In the same year, the internal ownership —including controlling families' indirect ownership through affiliates as well as their direct ownership - of these corporate groups accounted for $48.3 \% .{ }^{93}$ As a result, these families effectively exercised control over corporate groups. The Wallenberg family in Sweden is also famous for a huge discrepancy between their economic interests (or cash flow rights) and voting rights: for example, "the Wallenbergs have voting control over ABB [i.e., Sweden's fourth largest firm by market capitalization], but actually have a cash flow rights stake of only about 5 percent." 94

In the United States, "[Mark] Zuckerberg owns 28.4 percent of Facebook, the largest single stake in the company, and he extended his voting power by implementing a dual-class stock structure in 2009." 95

\footnotetext{
${ }^{91}$ In the United States, decision-makers of a corporation are formally directors on the board of directors. DeL. CoDE ANN. tit. 8, § 141(a) (2014) ("The business and affairs of every corporation organized under this chapter shall be managed by or under the direction of a board of directors, except as may be otherwise provided in this chapter or in its certificate of incorporation.").

92 See Nansulhun Choi \& Sang Yop Kang, Competition Law Meets Corporate Governance: Ownership Structure, Voting Leverage, and Investor Protection of Large Family Corporate Groups in Korea, 2 PeKIng U. Transnat'L L. ReV. 411, 422 (2014) (presenting data from the Korea Fair Trade Commission).

${ }^{93} I d$. The average internal ownership of the next six largest corporate groups accounted for $59.2 \%$. Id.

${ }^{94}$ Randall Morck et al., Corporate Governance, Economic Entrenchment, and Growth, 43 J. ECON. Literature 657, 665 (2005) (citing Rafael La Porta et al., Corporate Ownership Around the World, 54 J. FIN. 471 (1999)).

${ }^{95}$ Mark Zuckerberg: How Much Does He Make and What Does He Stand to Gain from IPO?, THE WASHINGTON POST (Feb. 2, 2012), http://www.washingtonpost.com/business/economy/mark-zuckerberg-how-much-does-hemake-and-what-does-he-stand-to-gain-from-ipo/2012/02/02/gIQAhJBElQ_story.html.
} 
Due to voting leverage giving "[him] shares with 10 times more voting power than common stock," however, "[h]is command of the company goes beyond stock-[Zuckerberg] controls 56.9 percent of the voting power." $" 96$

In China, Alibaba provides a good example of CMS. Before its initial public offering (IPO) in 2014, the largest shareholder of Alibaba was a Japanese corporation, Softbank, which owned 34.4\%, followed by Yahoo which owned $22.6 \% .^{97}$ The ownership of Jack Ma was merely $8.9 \%{ }^{98}$ Nonetheless, Alibaba's controlling shareholder was Jack Ma. Irrespective of economic interests, he used a partnership that had the power to nominate a majority of the members of the board. ${ }^{99}$ When Alibaba planned to list in a stock exchange, the Hong Kong stock exchange was a primary candidate. However, the Hong Kong stock exchange would not allow Alibaba to use a control device that was functionally equivalent to a one-share-multiple-vote mechanism. 100 Finally, Jack Ma and his partners chose to list Alibaba on the New York Stock Exchange (NYSE) where voting leverage was permitted. ${ }^{101}$

Indeed, CMS is a useful ownership mechanism for controlling shareholders since they can exercise control over corporations with only a small fraction of their direct ownership. In this light, it is expected that controlling family shareholders of large Chinese companies (or corporate groups) will have a stronger incentive to rely on CMS and use voting leverage devices such as stock pyramiding.

\section{Renunciation of Monopoly Profit Maximization: Investors' Loss and Consumers' Benefit}

\footnotetext{
${ }^{96} \mathrm{Id}$.

${ }^{97}$ See, e.g., Paul Hodgson, Alibaba IPO: Shareholders Can Buy Shares, Not Influence, FORTUNE (Sept. 18, 2014, 10:45 AM), http://fortune.com/2014/09/18/alibaba-iposhareholders; see also Joseph Tsai: Alibaba's Mega-Dealmaker, SHENZHEN DAILY (Sept. 19, 2014, 8:53 AM), http://www.szdaily.com/content/2014-09/19/content_10176909.htm.

${ }^{98}$ See Hodgson, supra note 97; see also SHENZHEN DAILY, supra note 97 . According to recent reports, Jack Ma's ownership was 7.6\% (as of August 2015). See, e.g., Gillian Wong, Alibaba's Jack Ma, Joe Tsai to Borrow \$2 Billion Against Shares, THE WALL STREET JouRnAL (Sep. 4, 2015, 4:32 AM), http://www.wsj.com/articles/alibabas-jack-majoe-tsai-to-borrow-2-billion-against-shares-1441355553.

99 Alibaba Partnership, AliBABA GROUP, http://www.alibabagroup.com/en/ir/ governance_9 (last visited Aug. 3, 2015) (explaining the Alibaba partnership's "director nomination right").

${ }^{100}$ See, e.g., Enda Curran, How Hong Kong Lost the Alibaba IPO, ThE Wall STREET JOURNAL (Mar. 15, 2014, 11:40 AM), http://www.wsj.com/articles/SB100014240 52702303546204579440820673013810.

${ }^{101}$ See Nicole Bullock et al., Alibaba Closes at $\$ 93.89$ in NYSE Debut, THE FinANCIAL TIMES (Sept. 20, 2014,, 12:36 AM), http://www.ft.com/intl/cms/s/0/8150f416-4002-11e4a381-00144feabdc0.html\#slide0.
} 
Since a controlling shareholder's ownership (or cash flow rights) is small in a CMS, the controller's personal economic interest is often not aligned with the corporation. If a CMS controller owns only $5 \%$ of a corporation, without tunneling, the controller is entitled to merely $5 \%$ of the cash flow rights from dividends and market capital appreciation. ${ }^{102}$ Consider such a case within the context of (quasi) monopoly. Although a CMS controller's economic interests are fractionally associated with the corporation's economic interests, monopoly profits are beneficial to a CMS controller as well. In general, a decision to maximize monopoly profits is optimal to a CMS controller. Due to the small percentage of ownership, however, the CMS controller's incentive to strictly follow the profit maximization strategy for the corporation can be weakened if there is an internal or external factor derailing an equilibrium of profit maximization.

For instance, when a government drives monopoly regulations such as a price stabilization policy, a CMS (quasi) monopoly corporation-before it challenges the regulation in the media or the judiciary-is likely to voluntarily give up its strategy of monopoly profit maximization. In addition, if a CMS controller is able to gain other types of large, personal benefits (either pecuniary or non-pecuniary), the controller has more reason not to maximize profits for the corporation. ${ }^{103}$ Also, if a CMS controller has unique characteristics, personal philosophies (e.g., a corporation as a means of philanthropy, as seen in Dodge ${ }^{104}$ or views, which are incompatible with the maximization of monopoly profits, the controlling shareholder would not actively pursue profits for the other shareholders.

Other things being equal, a CMS controller's tendency to deviate from monopoly profit maximization is further reinforced as a CMS controller's economic interests in a corporation decrease. In such a deep CMS, a CMS controller is likely to charge a lower price than Pm (i.e., the monopoly-profit maximizing price) and produce a larger quantity of a good than $Q m$ (i.e., the monopoly-profit maximizing quantity of a good

\footnotetext{
${ }^{102}$ Basically, shareholders have two types of rights in a corporation, i.e., cash flow rights and voting rights. Cash flow rights are not simply the right to receive dividends. Even if dividends are not paid, shareholders can realize their cash flow rights through stock price appreciation. In other words, cash flow rights are any pecuniary benefit that shareholders are entitled to attain on a pro-rata basis. Of course, in a bad-law jurisdiction, controlling shareholders expropriate from corporations (i.e., tunneling), taking more than their pro-rata cash flows. As a result, in reality public shareholders are not able to enjoy some of their cash flow rights.

${ }^{103}$ Other benefits are either pecuniary or non-pecuniary benefits.

${ }^{104}$ See supra Part II.A.1.
} 
produced to maximize monopoly profits). If so, public shareholders' wealth in the corporation is not optimized. ${ }^{10}$

Clearly, from the perspective of corporate governance, this is a minus factor. In theory, a CMS controller's lackluster approach with respect to shareholder primacy could amount to a breach of fiduciary duty, detrimental to shareholders. In reality, however, in most cases, the deferential business judgment rule protects the CMS controller (and managers or directors). ${ }^{106}$ This is because it would be almost impossible for public shareholders to rebut the presumption of reasonable business judgment. Indeed, Dodge is an exceptional case, where a majority shareholder is held liable for a corporation's "undesirable" dividend policy, which is generally considered to be within a board's discretion. In Dodge, a primary reason for the Court's ruling against the corporation's business decision (i.e., a dividend payout policy) is that Henry Ford showed in a bold manner - rather than disguised - his intention to put public welfare (for consumers and employees) before shareholders' economic interest. ${ }^{107}$ Other than a case of an explicit violation of the fiduciary duty to

\footnotetext{
${ }^{105}$ Most managers in a widely-held corporation in the United States have less economic interests in a corporation than a CMS controller. Then, a related question is: Do managers in a U.S. dispersed-shareholder corporation follow the shareholder primacy norm? To my knowledge, there is no convincing empirical evidence to answer this question. It is plausible, however, that the shareholder wealth maximization principle works at least better in the United States - although it does not work in a perfect manner - than in other countries. This is because the United States has many corporate governance mechanisms - again, although they do not perfectly work - that rectify relatively well managers' attempt to deviate from the shareholder wealth maximization principle. These corporate governance mechanisms include, but are not limited to, a business culture that respects the shareholder primacy norm, stock option arrangements, the presence of influential institutional investors, shareholder activism, competitive and sophisticated capital and product markets, a developed disclosure system, relatively effective independent directors, and the presence of relatively active markets for corporate control. For instance, a stock option arrangement can possibly align the interest of top managers with the interest of public shareholders. See, e.g., Roe, supra note 12, at 2075 (but also explaining the obstacles of implementing stock options in Europe). On the other hand, for a critical view of a typical stock option mechanism in the United States, see generally Lucian A. Bebchuk \& Jesse M. Fried, Pay Without Performance: Overview of the Issues, 30 J. CORP. L. 647 (2005) (critiquing existing executive pay arrangements and the corporate governance processes that produce them). Also, given that the topic of this Article is related to the tension among monopoly/oligopoly, shareholder wealth maximization, and national welfare (with consumer surplus), one more aspect that should be kept in mind is that monopolistic rents are less problematic in the United States, which has perhaps the most competitive product markets in the world. See supra Part II.B.2.

${ }^{106}$ See William T. Allen et Al., Commentaries and CASES on the LaW OF Business ORGANIZATION 227-28 (4th ed. 2012) ("The core idea [of the business judgment rule] is universal: Courts should not second-guess good-faith decisions made by independent and disinterested directors.").

${ }^{107}$ See id. at 272 ("Dodge v. Ford Motor Co. is unique precisely because Mr. Ford announced that he was acting in the interests of nonshareholders."); see also supra Part II.A.1.
} 
shareholders, there is little chance for a corporate insider to lose. Accordingly, public shareholders would not be able to recover damages. In addition, even if public investors recover damages in rare cases, they are often subject to the so-called circularity problem in derivative suits: a liable corporate insider is insured by director and officer insurance, for which the corporation (and thus, eventually shareholders) pays. ${ }^{108}$

From the perspective of the efficiency of the entire nation, however, a corporate insider's aberration from the best interests of the shareholders is a plus factor. For instance, the level of consumer surplus will be enhanced relative to a case where maximizing monopoly profits is pursued. Also, social welfare is improved, since the amount of DWL will decrease. Consider both (quasi) monopoly and CMS on a stand-alone basis: (quasi) monopoly is generally considered an undesirable form of industrial organization due to the welfare loss. In addition, CMS is generally considered a problematic ownership structure, due to a controlling shareholder's disproportionate decision-making power. When these two negative aspects are combined - what I call the "square of a bad" (or "Bad") —ironically, a positive outcome for national welfare may arise.

\section{CMS Controller's Collective Action Problem}

In corporate governance scholarship, a theory of a collective action problem is often used to explain a case where non-controlling shareholders have difficulties when challenging corporate insiders in a proxy fight. ${ }^{109}$ The key factor of the collective action problem is thatfrom a viewpoint of a non-controlling shareholder who challenges in a corporation's election (and voting) - the costs of the challenge will be concentrated on him or her while the benefits from the challenge will be shared with other shareholders (i.e., free-riders). ${ }^{110}$ In contrast to the traditional collective action problem non-controlling shareholders face in a proxy fight, this Subsection suggests another type of collective action problem that a CMS controller faces in relation to profit maximization in (quasi) monopoly.

(Quasi) monopolistic rents enlarged by shareholder wealth maximization are problematic to consumers, government agencies, and the

\footnotetext{
${ }^{108}$ See, e.g., Ehud Kamar, Shareholder Litigation Under Indeterminate Corporate Law, 66 U. CHI. L. REV. 887, 887-88 (1999) ("Arguably, there is no utility for shareholders in suing corporate fiduciaries for damages when fiduciaries pay most of these damages using funds provided by shareholders.").

${ }^{109}$ See, e.g., ALLEN ET AL., supra note 106, at 371 (explaining the concept of a collective action problem in a context of corporation).

${ }^{110}$ See, e.g., Bernard S. Black, Agents Watching Agents: The Promise of Institutional Investor Voice, 39 UCLA L. REV. 811, 821 (1992) ("[A] shareholder proponent bears most of the cost of a proxy campaign, but receives only a pro rata share of the gains from success, while other shareholders can free ride on her efforts.").
} 
general public. As the ultimate decision-maker of a corporation, it is likely that a CMS controller who maximizes shareholder wealth would be personally subject to criticism or even (official or unofficial) punishment. If so, on the one hand, the costs-namely, criticism or (official or unofficial) punishment arising from the monopoly profit maximizationfall mostly on the CMS controller. On the other hand, the benefits from maximizing profits in monopoly or oligopoly will be shared with noncontrolling public shareholders who hold the vast majority of the economic interests in the corporation. Again, the CMS controller's fraction is small proportional to his or her ownership. Taking into account the fact that the costs are concentrated but the benefits are dispersed, the CMS controller's incentive to maximize monopoly profits would be weakened.

\section{B. Deviation from Shareholder Wealth Maximization}

Previously, Section A provided general explanations for the lack of a CMS controller's incentive to maximize monopoly profits. Now, Section B explains, by introducing related accounts and examples, how a CMS controller deviates from shareholder wealth maximization. Specifically, Section B reviews a CMS controller's preference of the size of a corporation over profitability, and his or her personal philosophy, which can potentially lower the profitability of a corporation. This analysis also provides a useful foundation for predicting the behavior and business decisions of controlling family shareholders in China. If controlling family shareholders in China use CMS more frequently, it is likely that they will pay less attention to shareholder primacy.

\section{CMS Controller's Size Preference}

A CMS controller, depending on the cultural values of specific jurisdictions, may be more interested in size maximization than in profit maximization. This is partly because a CMS controller is able to enjoy non-pecuniary benefits by running a large corporation. ${ }^{111}$ Ruling a corporation as a king is fun and exciting. Controlling shareholders tend to expand corporate territory as much as possible, like Genghis Khan, raising

111 See Ronald J. Gilson, Controlling Shareholders and Corporate Governance: Complicating the Comparative Taxonomy, 119 HARV. L. REV. 1641, 1664 (2006) ("[C]ontrol of a large company in a small economy may provide a desirable social status for the controlling family."); see also George W. Dent, Jr., Unprofitable Mergers: Toward a Market-Based Legal Response, 80 Nw. U. L. REV. 777, 781 (1986) ("Corporate managers may seek growth of firm size rather than maximization of share price in order to justify better compensation and perquisites, to increase prestige, to expand opportunities for promotion, and, perhaps most importantly, to protect themselves from the discipline of the market."); Kang, supra note 26, at 870-73 (explaining the concept of empire-building-i.e., increasing the size of a corporation-and non-pecuniary benefits). 
their self-esteem, even if some level of pecuniary benefits is sacrificed. In Korea, the President sometimes has meetings with business leaders. In these meetings, the physical distance between the President's seat and the business leaders' generally depends on the asset size or sales of their corporate groups (rather than profitability). ${ }^{112}$ Business elites perceive the opportunity to talk and take a photo with the person in power as a measurement of their success. In addition, the size of a business is, at least sometimes, more significant than the level of profitability since a corporation's size provides negotiating and political power.

It is significant that while pecuniary benefits from (quasi) monopoly profits accrue to a CMS controller on a pro-rata basis (e.g., $5 \%$ ), non-pecuniary benefits belong to him or her almost exclusively. ${ }^{113}$ Thus, the non-pecuniary benefits from managing a large business enterprise as a corporate dictatorship are private benefits that only the CMS controller, despite his or her fractional ownership, can enjoy. ${ }^{114}$ In reality, CMS controllers do not choose solely on the basis of size maximization or profit maximization. ${ }^{115}$ Rather, they compromise between these two poles. In any case, the pure profit maximization strategy is not selected.

In addition, the large size of a corporation provides the corporation with a variety of opportunities. For instance, large corporations, particularly in developing countries where capital markets are not developed, have a comparative advantage in raising capital (either equity or debt), entering into a new regulatory industry, and obtaining a

\footnotetext{
${ }^{112}$ See, e.g., Yoon-Joo Lee (이윤주) et al., Gwonryeokja yeopjarineun 'himui seoyeol' . . . Junkyungryun hoejangboda jaegye sunwiro (권력자 옆자리는 '힘의 서열' . . . 전경련 회장보다 재계 순위로) [Seat Next to President Chosen by 'Ranks of Power' . . . Given to Person with Biggest Market Capitalization Not President of Federation of Korean Industries], THE KyUnghyANG SHINMUN (May 19, 2014, 9:22 PM), http://bizn.khan.co.kr/khan_art_view.html?artid=201405191520161\&code=920509\&med= khan (explaining that the power of business entities, including banks, is generally measured by their asset size).

${ }^{113}$ See, e.g., Kang, supra note 26, at 876 (describing a controlling shareholder as the beneficiary of non-pecuniary benefits).

${ }^{114} I d$. In the example of "sitting next to the President," it can be said that public shareholders indirectly benefit from a controlling shareholder's attempt to enlarge the size of a business entity. This is because media attention brought to a large business entity could strengthen confidence for the business in both a product market and a capital market. ${ }^{115}$ Under the size maximization case, it is known that the quantity of a good is determined where the total revenue (TR) is equal to the total cost (TC). Compare with the profit maximization case, where the quantity of a good is determined where the marginal revenue (MR) is equal to the marginal cost (MC).
} 
"survival insurance" because they are "too-large-to-fail." 116 If these benefits go directly to corporations rather than controlling shareholders, benefits are shared with-though not necessarily on a pro-rata basispublic shareholders.

When a CMS controller pays attention to the size of the corporation and deviates from the pure shareholder wealth maximization norm, the controller decides to increase the quantity of a good produced by a monopoly corporation from $Q m$ towards $Q c^{117}$ (thus, the final quantity would be $Q s$ which is situated between $Q m$ and $Q c$ ). The economic interests of public shareholders will be damaged because the monopoly profits raised by market power will shrink. ${ }^{118}$ On the other hand, for the same reason, the amount of consumer surplus will be enlarged. The overall level of welfare for a domestic economy would be enhanced as DWL diminishes. ${ }^{119}$ As discussed in the "square of a bad" (or "Bad"), ${ }^{120}$ a CMS with (quasi) monopoly might generate a better consequence - the combination of a high level of output and low pricefor consumers and society. ${ }^{121}$

Of course, it does not say that the "square of a bad" is optimal in absolute terms. Given the (quasi) monopoly, for instance, the quality of a good or service will not be improved due to the lack of meaningful competition in a market. X-inefficiency ${ }^{122}$ and other problems associated with CMS and monopoly (e.g., business-politics collusion) also should be recognized. ${ }^{123}$ In particular, corporate insiders' shirking usually takes place in a (quasi) monopoly. In this respect, the positive aspect of the "square of a bad" merely indicates that the situation is "better than we had thought" in relative terms. This limited interpretation of the "square of a bad" is useful to examine the current and future markets in China.

\section{Controlling Shareholder's Personal Philosophy}

A business tycoon's personal philosophy may also negatively affect shareholder wealth maximization. As discussed previously, ${ }^{124}$

\footnotetext{
${ }^{116}$ Many scholars analyze the phenomenon of "too-large-to-fail" in a context of financial institutions and corporations. See, e.g., Kang, supra note 26 at 880-81 (explaining toolarge-to-fail as a form of insurance).

${ }^{117}$ As explained earlier, $Q m$ stands for the quantity produced by a monopoly corporation when it follows monopoly profits maximization. $Q c$ stands for the quantity produced in a competitive market.

${ }^{118}$ It is also useful to analyze this phenomenon based on supra Figure 1.

${ }^{119}$ See id.

${ }^{120}$ See supra Part III.A.2 (explaining the "square of a bad" (or "Bad $\left.{ }^{2 ")}\right)$ ).

${ }^{121}$ Note that this explanation is based on "no-tunneling." As to a further analysis with tunneling, see infra Part III.C.

${ }^{122}$ See infra note 156 and accompanying text.

${ }^{123}$ See infra Part III.D.

${ }^{124}$ See supra Part II.A.1 (explaining Dodge).
} 
Henry Ford's philosophy of philanthropy for employees, consumers, and society is exemplary. ${ }^{125}$ Almost a century later, intriguingly, Alibaba's Jack Ma introduced a unique business philosophy similar to Henry Ford's. ${ }^{126}$ In a letter to employees before the company's IPO, Jack Ma confirmed that Alibaba believed in the principle of "customer first, employee second, shareholder third": ${ }^{127}$

In a few minutes we will officially submit our initial registration statement to the U.S. Securities and Exchange Commission. This means Alibaba is about to enter a new era of challenges ... After we go public, we would continue to adhere to the principle of "customer first, employee second, shareholder third." We believe that, no matter what difficult decisions we face whether now or in the future, sticking with our principles is the best way to respect and protect the interests of all parties. ${ }^{128}$ (emphasis added).

A few additional points about this letter are worth noting. Most of all, this letter explicitly shows Jack Ma's belief in "customer primacy," as opposed to "shareholder primacy." 129 No matter whether "customers" refer to sellers or purchasers of the Alibaba platform, the letter may convey that Alibaba would give up maximizing profits belonging to shareholders. ${ }^{130}$ Since Jack Ma's economic interest in Alibaba is less than

\footnotetext{
${ }^{125}$ Note, however, that Henry Ford's decision not to pay a sufficient level of dividends to shareholders (particularly the Dodge brothers) can be also explained by his business strategy rather than his philanthropy. See ALLEN ET AL, supra note 106, at 271 ("In 1913, the Dodge brothers announced that they would stop building cars for Ford, and would design, build, and sell their own car ... In 1916, Ford announced that his company would stop paying dividends, in an attempt to cut off the cash flow that fueled his rivals' business.").

${ }^{126}$ Currently, I am considering an independent project in relation to Alibaba and investor protection. This Section's explanation of Alibaba is from the initial research for this project.

${ }^{127}$ See, e.g., 'Unparalleled Ruthlessness' Awaits: Jack Ma's Letter to Alibaba Employees, THE WALL STREET JOURNAL (May 7, 2014, 12:13 PM), http://blogs.wsj.com/chinarealtime/2014/05/07/unparalleledruthlessness-awaits-jack-mas-letter-to-alibaba-employees/ (introducing Jack Ma's e-mail to Alibaba's employees).

${ }^{128}$ See id (quoting Jack Ma's e-mail to Alibaba's employees).

${ }^{129}$ Alternatively, it is possible that the principle of "customer first, employee second, shareholder third" is merely Alibaba's (or Jack Ma's) general business slogan. If so, the principle does not necessarily hurt the interest of shareholders in Alibaba, since it can be construed that the principle is merely a marketing phrase to attract customers.

${ }^{130}$ Since Alibaba is the largest e-commerce company in China, it is generally explained that Alibaba is a (quasi) monopolist with significant market power. As to the Alibaba's market share in China, see Adam Jourdan, Surviving Chairman Ma: Life in the Shadow of China's Alibaba, REUTERs (Nov. 26, 2013, 4:20 PM), http://www.reuters.com/article/uschina-ecommerce-idUSBRE9AP17H20131126 ("Alibaba accounts for half of online retail
} 
$10 \%,{ }^{131}$ he bears a small percentage of the lost monopoly profits. This opportunity cost is the price for realizing his personal belief. I do not downplay Jack Ma's sincere desire for philanthropy. However, given his net-worth of 24.5 billion dollars, ${ }^{132}$ keeping faith in his business may be more valuable to him than additional pecuniary benefits. It is possible that the "marginal utility" 133 of pecuniary benefits - the additional satisfaction of an additional dollar - is tiny, or even close to zero at his level of wealth.

Sometimes, corporate insiders maintain a business line closely related to their hobbies as a "pet project." This type of externalization is detrimental both to shareholders and society. Compared to spending resources for a "pet project," complying with a personal belief for "customer primacy" in Alibaba could be more desirable. Nonetheless, more than $90 \%$ of the opportunity cost, in relation to the renunciation of maximized monopoly profits, will be borne by shareholders other than Jack Ma. In this light, it is theoretically possible that public shareholders may bring a suit since shareholder wealth is a subordinate ideology to the welfare of customers and employees in Alibaba (the argument of shareholders would be based on Dodge to some extent). ${ }^{134}$

sales through its Tmall online market while its eBay like Taobao also controls around 80 percent of consumer to consumer online sales, according to data from consultancy Euromonitor . . . By comparison, China's second largest ecommerce firm Jingdong, or JD.com, has a nearly 13 percent market share.”); Kathy Chu \& Gillian Wong, Alibaba vs. JD.com: Executives Weigh In, The Wall Street Journal (Aug. 17, 2015, 2:45 AM), http://www.wsj.com/articles/alibaba-vs-jd-com-executives-weigh-in-1439793927

("Alibaba Group Holding Ltd. remains the giant, capturing nearly 59\% of China's fastgrowing business-to-consumer marketplace . . . JD.com's share was $23 \%$ in the first quarter of 2015 . . .."). On the other hand, it might also be explained that Alibaba is not a firmly established (quasi) monopolist due to the competitive features of e-commerce (e.g., competition with Jingdong). If so, Alibaba's "customer first" policy can be explained by the potential competition in the market, as well as by Jack Ma's personal philosophy for customers (and society).

${ }^{131}$ See supra note 98 and accompanying text (explaining that Jack Ma's ownership before the IPO was $8.9 \%$ and his recent ownership as of August 2015 was 7.6\%).

${ }^{132}$ See, e.g., Paul Carsten, Alibaba's Jack Ma Dethroned as China's Richest by Solar Magnate: Report, REUTERS (Feb. 3, 2015, 5:27 AM), http://www.reuters.com/article/2015/02/03/us-china-wealth-idUSKBN0L70WA20150203 (stating that Jack Ma and his family's personal wealth is $\$ 24.5$ billion).

${ }^{133}$ Marginal utility is "the additional satisfaction or benefit (utility) that a consumer derives from buying an additional unit of a commodity or service." See BRITANNICA, http://global.britannica.com/topic/marginal-utility (last visited Aug. 6, 2015). It is known that marginal utility diminishes. See KRUGMAN \& Wells, supra note 6, at 252 ("each successive clam adds less to total utility than the previous clam.”).

${ }^{134}$ Alibaba may argue that its customer-friendly policy will be, in the long run, beneficial to shareholders. See also supra note 129. In practice, however, it would be difficult for public shareholders in the United States to bring suit against corporate insiders of Alibaba. It is partially because Alibaba is incorporated in Cayman Islands. Presentation of Professor Jesse Fried at Harvard Law School (Seminar at Peking University Law School, Nov. 2, 2015). 


\section{Tunneling and (Quasi) Monopoly Profits}

So far, Part III has explored a CMS controller's incentive issues without considering tunneling. Section $\mathrm{C}$ examines the impacts of tunneling on shareholder wealth maximization and on the welfare of shareholders, consumers, and the nation in a (quasi) monopoly environment. In this analysis, three suboptimal aspects are combined: (1) bad industrial organization (i.e., monopoly); (2) bad ownership structure (i.e., CMS); and (3) bad corporate law (i.e., tunneling). I call this combination the "cube of a bad" (or "Bad"). The "cube of a bad" has implications for controlling family shareholders of large corporate groups, particularly in China where the quality of corporate governance is poor (and thus tunneling is not effectively kept in check).

In regard to the extent of tunneling, three scenarios are considered in the following Subsections: (1) Tunneling of Substantially All of Corporate Assets (e.g., tunneling of an additional 85\%); (2) Small-Scale Tunneling (e.g., tunneling of an additional 3\%); and (3) Significant Levels (But Not Substantially All) of Tunneling (e.g., tunneling of an additional $25 \%$ ). In these scenarios, a hypothetical CMS controller holds a 5\% economic interest in a corporation. Since numerical examples of the level of tunneling $(85 \%, 3 \%$, and $25 \%)$ are selected merely for simplicity purposes, a more generalized model can be further developed and suggested. ${ }^{135}$

\section{Tunneling of Substantially All of Corporate Assets (e.g., Tunneling of an Additional 85\%)}

Suppose that a CMS controller, holding a 5\% of economic interest in a corporation, is able to expropriate $85 \%$ of corporate value in addition to justified $5 \%$ cash flows. Such drastic plundering may take place in a severely tainted bad-law jurisdiction, either because corporate law in itself is imperfect or because the enforcement system - although the law-on-thebook is perfect-is ineffective. ${ }^{136}$ Under these circumstances, the controller's personal economic incentive-due to the combined effect of legitimate and unjustified cash flow rights — aligns almost exactly with

\footnotetext{
${ }^{135}$ See infra Part III.D.

${ }^{136}$ See, e.g., Ronal J. Gilson, Controlling Family Shareholders in Developing Countries: Anchoring Relational Exchange, 60 STAN. L. REV. 633, 634 (2007) ("The law and finance literature, exemplified by a series of articles by Rafael La Porta, Florencio Lopez-deSilanes, Andrei Shleifer, Robert Vishny and others, treats the prevalence of controlling shareholders as the result of bad law."). However, Gilson explains that some controlling shareholder regimes are good-law countries. Gilson, supra note 111, at 1645 (explaining that Sweden - a controlling shareholder regime - is a good-law country).
} 
that of the corporation since the controller takes $90 \%$ of corporate value. ${ }^{137}$ Accordingly, it is highly likely that the controller will pursue monopoly profit maximization. A caveat from the CMS controller's standpoint, however, is that in the next stage, public shareholders of the pillaged corporation would be highly reluctant to invest further and, thus, will leave the corporation. For that reason, a CMS controller's extensive tunneling is likely a one-time event. A CMS controller, who wishes to remain as a repeat player, such as a controlling family shareholder who intends to stay in a corporation for a long time via inheritance, would not depend on massive tunneling. ${ }^{138}$

Nevertheless, if massive tunneling occurs, the result will be the worst from both the aspects of shareholder primacy and social welfare: (1) the financial interests of public investors will be severely damaged; (2) due to public shareholders' distrust in their investment in corporations, further development in a capital market is unlikely; (3) a large amount of consumer surplus will be transferred to a monopoly corporation, where the CMS controller takes $90 \%$ of economic interests; and (4) a gigantic amount of DWL would be created.

\section{Small-Scale Tunneling (e.g., Tunneling of an Additional 3\%)}

Suppose that a CMS controller with 5\% ownership in a monopoly corporation relies on a strategy of small-scale tunneling and takes an additional $3 \%$ of corporate value on top of the justified $5 \%$ cash flows. This scenario of modest tunneling by a controlling shareholder is a more realistic repeated-game arrangement in a bad-law jurisdiction if public investors and a controlling shareholder have a long time horizon. ${ }^{139}$ Perhaps a controlling shareholder would like to rely on substantial plundering; however, the controller might believe that substantial plundering is too risky in terms of legal repercussions and enforcement. Although the $3 \%$ level looks low in this scenario, ${ }^{140}$ the CMS controller's

\footnotetext{
${ }^{137}$ In this hypothetical example, a CMS controller's legitimate cash flow rights are 5\%, while unjustified cash flow rights are $85 \%$. Thus, the total cash flows are $90 \%$.

${ }^{138}$ Thus, this scenario of massive tunneling is ruled out in a jurisdiction based on controlling family shareholders with corporate groups, except for a slim chance that public shareholders are still satisfied with the remaining profits. Although it is a remote possibility, theoretically, it is possible that public shareholders with $95 \%$ cash flow rights are satisfied (though not perfectly satisfied) with $10 \%$ of actual cash flows. In that case, they would remain in a corporation as public shareholders.

${ }^{139}$ This type of controlling shareholder is referred to as a "stationary controller" who periodically extracts a part of corporate value. The other type of controlling shareholder is a "roving controller" who plunders the entire corporate value at once. See generally Kang, supra note 28 (explaining a "stationary controller" and a "roving controller").

${ }^{140}$ Note that I do not have in mind any specific controlling family shareholder who relies on $3 \%$ tunneling. It is extremely difficult to understand the extent of tunneling, which usually takes place in secret. $3 \%$ is merely a numerical example in this hypothetical case.
} 
"extra return" (i.e., 3\% tunneling) on the "initial investment" (i.e., 5\% cash flow rights) is huge $(60 \%) .{ }^{141}$ The CMS controller with small-scale tunneling has still a weak incentive to pursue monopoly profit maximization, since the controller's total cash flows are merely $8 \%{ }^{142}$ It is noteworthy, however, that a CMS controller with small-scale tunneling has a stronger incentive for profit maximization than a CMS controller without tunneling, whose justified cash flow rights account for $5 \%$ in a corporation. To some extent, shareholder wealth maximization, ironically, can be supported by tunneling.

An interesting and contradictory phenomenon emerges in the context of shareholder protection when a CMS controller relies on tunneling. On the one hand, public shareholders are less protected, since a controller takes the public shareholders' wealth reserved in a corporation. On the other hand, public shareholders may gain more economic benefits, due to the controller's relatively stronger incentive to maximize monopoly profits. ${ }^{143}$ Thus, modest tunneling has a mixed impact on shareholders. Subsequently, consider the impact of the modest tunneling on social welfare relative to a situation with no tunneling. Tunneling, even if it is modest, strengthens a CMS controller's incentive to follow monopoly profit maximization. Thus, the CMS controller will move up price towards $P m$. As a result, consumers will be worse off and the DWL will be larger. This will lower the level of national welfare.

Examine tunneling in China. Some controlling shareholders expropriate substantially all of corporate assets. For example, "[in 2001], the largest shareholder of Sanjiu Pharmacy extracted \$301.9 million or $96 \%$ of this listed company's total equity." 144 As time goes by, corporate governance systems in China will stabilize and more controlling family shareholders, who intend to stay in their controlled corporations for a long time, will emerge as repeat players. ${ }^{145}$ Then, although it is difficult to entirely rule out tunneling of substantially all corporate assets, a modest level of extraction will be dominant in the future. If so, this Subsection will provide a useful framework to analyze the interaction of (quasi) monopoly, CMS, and modest tunneling in China.

\footnotetext{
${ }^{141} 3 \% \div 5 \%=0.6$ (which is equivalent to $60 \%$ return-on-equity). Accordingly, this situation is also attractive to the CMS controller.

${ }^{142}$ In this hypothetical example, a CMS controller's original cash flow rights are 5\%, while unjustified cash flow rights are $3 \%$. Thus, the total cash flows are $8 \%$.

${ }^{143}$ It is noteworthy, however, that a CMS controller in this example has only $3 \%$ more economic incentives. Accordingly, his or her incentive to follow shareholder primacy will be slightly strengthened. As a result, benefits for public shareholders could be limited. Ultimately, how much public shareholders indirectly benefit from a controller's tunneling is an empirical question.

${ }^{144}$ See Chong-En Bai et al., Corporate Governance and Market Valuation in China, 32 J. Comp. ECON. 599, 600 (2004).

${ }^{145}$ See generally Kang, supra note 28 (explaining a stationary controller as a repeat player).
} 


\section{Significant Levels of Tunneling (e.g., Tunneling of an Additional 25\%)}

If a CMS controller with 5\% ownership of a monopoly corporation takes a significant amount, but not substantially all, of corporate value (e.g., taking $25 \%$ of corporate value beyond the justified $5 \%$ of cash flows), the controller has more incentive to pursue monopoly profit maximization than a controller with tunneling of 3\%. As a result, price would increase further towards $P m$ and quantity would decrease towards Qm. Again, the effect on shareholder protection is not straightforward. On the one hand, the size of tunneling is significant and harms public shareholders. On the other hand, when the CMS controller arduously pursues monopoly profits, public shareholders are likely to receive - at the expense of consumers - a significant portion of these profits, albeit on less than a pro-rata basis. ${ }^{146}$

In light of this, it is difficult to label the public shareholders in a bad-law jurisdiction - though their cash flow rights are taken by a controlling shareholder-as "unilateral victims" due to the wealth transfer from consumers to all of the shareholders (public shareholders as well as a controller). ${ }^{147}$ If monopoly rents are generated due to an unduly high price charged by a monopoly corporation, it can be said that consumers are exploited by the corporation. Public investors in the monopoly corporation benefit from the wealth transfer even if they do not actively participate in such "exploitation." ${ }^{148}$ In different terms, public shareholders are on the same ship with the main exploiter - the monopoly corporation (or its controlling shareholder). This analysis can also apply to controlling family shareholders in China if they use CMS in corporate groups and rely on significant (but not substantially all) level of tunneling, given (quasi) monopoly.

One may point out that public shareholders obtain only $70 \%$ of monopoly profits while they are entitled to $95 \%$ of cash flow rights in a corporation. ${ }^{149}$ The logic may continue that public shareholders lose $25 \%$ of economic benefits ${ }^{150}$ and, thus, they are still victims. However, if monopoly profits are "rents" in favor of the entire shareholder group (i.e., both a controller and public shareholders) to the detriment of consumers, it

\footnotetext{
${ }^{146}$ Note that in this case, public shareholders own $95 \%$ of economic interests in the corporation. Also, note that in this case, public shareholders end up with $70 \%$ of monopoly profits, since $25 \%$ of profits are taken by a controller's tunneling (i.e., $95 \%$ $25 \%=70 \%$ ).

${ }^{147}$ See Kang, supra note 26, at 894.

${ }^{148}$ Sometimes, however, it is likely that public shareholders, as investors of a monopoly corporation, demand actively to charge the price $(\mathrm{Pm})$ that maximizes monopoly profits.

149 See supra note 146 .

${ }^{150} 95 \%-70 \%=25 \%$.
} 
can be said that public shareholders benefit $70 \%$ more, rather than lose $25 \%$. In addition, whether it is 95:5 or 70:30 between public shareholders and a controller, the internal allocation of exploited resources within an exploiting entity does not matter from the standpoint of the consumers who are the ultimate victims in this case. ${ }^{151}$ Accordingly, consumers may feel that public shareholders - who may claim that they suffer from a controller's tunneling - are merely weaker exploiters who capture rents that consumers could have benefitted from.

\section{Comparison of All Scenarios}

In Scenario 3 (tunneling of $25 \%$ ), the controller has a greater incentive to maximize monopoly profits than a CMS controller in Scenario 2 (tunneling of 3\%), but less incentive than a CMS controller in Scenario 1 (tunneling of $85 \%$ ). Thus, the monopoly price charged in Scenario 3 is likely to be in between the price in Scenario 1 (highest) and that in Scenario 2 (lowest). However, recall that the price in Scenario 2 is likely to be higher than in the case where no tunneling takes place at all. Due to a CMS controller's sufficient incentive to approach $P m$ and $Q m$ in Scenario 3, the social welfare is damaged through a large amount of DWL: DWL in Scenario 3 is larger than in Scenario 2, but smaller than in Scenario 1. Table 2 summarizes the three scenarios discussed in this Section.

Table 2: Extent of Tunneling, Monopoly Profit Maximization, DWL, and Social Welfare

\begin{tabular}{|c|c|c|c|}
\hline & $\begin{array}{c}\text { SCENARIO 1 } \\
\text { (TUNNELING } \\
\text { OF 85\%) }\end{array}$ & $\begin{array}{c}\text { SCENARIO 2 } \\
\text { (TUNNELING } \\
\text { OF 3\%) }\end{array}$ & $\begin{array}{c}\text { SCENARIO 3 } \\
\text { (TUNNELING } \\
\text { OF 25\%) }\end{array}$ \\
\hline $\begin{array}{c}\text { CMS } \\
\text { Controller's } \\
\text { Incentive to } \\
\text { Maximize } \\
\text { Monopoly Profits }\end{array}$ & Strong & Weak & Semi-Strong \\
\hline Price & High & Low & In-between \\
\hline Quantity & Small Amount & Large Amount & In-between \\
\hline DWL & Large & Small & In-between \\
\hline
\end{tabular}

\footnotetext{
${ }^{151}$ Monopoly rents will be distributed by the ratio of 95:5 (public shareholders v. a CMS controlling), if tunneling does not take place at all. However, rents will be distributed by the ratio of 70:30 if tunneling of $25 \%$ applies.
} 


\begin{tabular}{|l|l|l|l|}
\hline Social Welfare & Worst & Best & In-between \\
\hline
\end{tabular}

\section{Summary and Other Considerations}

Consider a simple, general model based on variables rather than specific numerical examples. In this model, a CMS controlling shareholder's cash flow rights (i.e., economic interests in a corporation) and the level of tunneling are denoted as " $\alpha$ " and " $\beta$," respectively. For example, when a CMS controller holding a $5 \%$ economic interest in a corporation does not rely on tunneling at all, $\alpha$ is $5 \%$ and $\beta$ is $0 \%$. When the CMS controller takes an additional $25 \%$ of corporate value, $\alpha$ is $5 \%$ and $\beta$ is $25 \%{ }^{152}$ A CMS controller's total cash flows in a corporation, including tunneling, are calculated as " $\alpha$ plus $\beta$." Based on this general model, the analysis of Part III can be summarized by two cases: the "case without tunneling" (i.e., $\beta=0$, and thus the situation of good-law) and the "case with tunneling" (i.e., $\beta>0$, and thus the situation of bad-law).

First, consider the "case without tunneling." Since the value of $\beta$ is zero, only the value of $\alpha$ matters. Given (quasi) monopoly of a certain jurisdiction, as an average controller's cash flow rights decrease (i.e., as the value of $\alpha$ becomes smaller), four outcomes are likely. (1) The profit maximization norm is less likely to be pursued, since controllers with a smaller $\alpha$ (particularly deep CMS controllers) have a weaker incentive to maximize profits. (2) Accordingly, public minority shareholders are likely to be worse off. (3) It is likely, however, that DWL will be reduced, since corporations move away from monopoly-profit maximizing price and quantity. As a result, social welfare will be improved. (4) Also, the welfare of consumers will be enhanced, since controlling shareholders with a low level of economic interests have lukewarm incentive to maximize monopoly profits.

Due to monopoly (i.e., bad industrial organization) and deep CMS (i.e., bad ownership structure), the case without tunneling is referred to as the "square of a bad" (or "Bad"). ${ }^{153}$ Outcomes (1) and (2), which are related to investor protection, are easily understandable. In contrast, outcomes (3) and (4), which are associated with efficiency and social welfare, are counter-intuitive to some extent. This is because "positive" outcomes - the welfare of consumers and the nation as a whole is enhanced-arise, when two "negatives" are combined. Sections A and B in this Part are basically explained based on the case without tunneling.

Subsequently, examine the "case with tunneling" where the value of $\beta$ is not zero. Given monopoly in a jurisdiction, as an average CMS controller's tunneling becomes more serious (as the value of $\beta$ becomes larger), another four outcomes are likely. (1) The profit maximization

\footnotetext{
${ }^{152}$ See supra Part III.C.3.

${ }^{153}$ See supra Part III.A.2.
} 
norm is more likely to be pursued, since the alignment of economic interests between CMS controllers and monopoly corporations is reinforced. ${ }^{154}$ (2) The welfare of public shareholders is affected in a mixed manner. On the one hand, due to more serious tunneling (as the value of $\beta$ becomes larger), public shareholders are likely to be worse off. On the other hand, the larger value of $\beta$ provides CMS controllers with stronger incentive to pursue monopoly profit maximization, which ends up yielding more benefits to all of the shareholders. (3) DWL is likely to be larger, since the corporation is going to move towards the monopoly-profit maximizing price and quantity. Accordingly, national welfare would be harmed. ${ }^{155}$ (4) In addition, the level of consumer surplus would worsen, as the price close to $P m$ is chosen and wealth transfers from consumers to the monopoly corporation.

Due to monopoly (i.e., bad industrial organization), deep CMS (i.e., bad ownership structure), and tunneling (i.e., bad corporate governance), the case with tunneling is referred to as "cube of a bad" (or "Bad" $\left.{ }^{3 "}\right)$. In this case, outcomes (1) and (2) are, to some extent, counterintuitive. In (1), interestingly, tunneling - despite its negative connotation in terms of investor protection - reinforces a CMS controller's incentive to follow profit maximization, which is beneficial to public shareholders. As a result, in (2) the damage caused by tunneling to public shareholders will be mitigated by enhanced shareholder wealth maximization.

In sum, when CMS is combined with (quasi) monopoly and/or tunneling, positive outcomes may inadvertently arise. Nonetheless, it is worth noting that this Article does not disagree with the classic, critical views of (quasi) monopoly, CMS, and tunneling. Indeed, (quasi) monopolies generate many problems. For instance, a corporation in a (quasi) monopoly market does not have to improve corporate efficiency due to the lack of competition. Thus, a monopoly corporation's internal inefficiency, such as "X-inefficiency," may arise. ${ }^{156}$ In addition, when an active market for corporate control ${ }^{157}$ does not exist—which is true in many jurisdictions - it is extremely difficult to rectify corporate insiders' slack in a monopoly corporation. In other words, this type of monopolist is subject to virtually no external pressure from M\&A and product markets. Also, CMS generally creates bad outcomes in corporate governance.

\footnotetext{
${ }^{154}$ See, e.g., supra Table 2 and accompanying text.

${ }^{155}$ See id.

${ }^{156}$ See Oliver D. Hart, The Market Mechanism as an Incentive Scheme, 14 BELL J. ECON. 366, 366 (1983) (stating that given the lack of competition, X-inefficiency is measured by "the amount of slack in the system due to individuals' not minimizing costs or being on their production possibility frontiers").

${ }^{157}$ See, e.g., Bernard S. Black, The Legal and Institutional Preconditions for Strong Securities Markets, 48 UCLA L. REV. 781, 842 (2001) ("[A]n active market for corporate control . . . can indirectly monitor performance and partly substitute for weaker direct shareholder oversight.").
} 
Particularly, when CMS is associated with tunneling, it has a huge negative effect on investor protection. Moreover, it is problematic that CMS controllers - usually, a small number of business tycoons in a jurisdiction - are likely to have political connections with a government; they and their business associations often seek economic rents in an unfair manner. ${ }^{158}$

These problems, however, are well known and already studied closely by economists, corporate law scholars, practitioners, and policymakers. Thus, this Article, concurring with such general opinions, does not redundantly explain the same points. Rather, this Article focuses on novel findings and analyses. It is also noteworthy that this Article provides an analytical framework for CMS and/or tunneling, given that (quasi) monopoly is firmly established in a certain jurisdiction and, at least in the short or medium term, it is impractical to reform the jurisdiction's imperfect industrial organization. Under these circumstances, shareholder wealth maximization may result in unintended outcomes.

\section{STATE-OWNED ENTERPRISES IN CHINA: (QUASI) MONOPOLY AND SHAREHOLDER WEALTH MAXIMIZATION}

Regarding the tension between shareholder maximization and (quasi) monopoly, Part III explored two factors - CMS and tunnelingthat Roe did not emphasize in his research. Subsequently, Part IV theoretically examines the possible tension in the context of Chinese SOEs, another factor that Roe's research does not cover. Two points are worth noting in relation to the following analysis in Part IV. First, the analysis focuses specifically on SOEs which are (quasi) monopolies in domestic markets. ${ }^{159}$ Second, although the theoretical approach in Part IV might also apply to similarly situated SOEs in other countries, China is perhaps the most important example of the analysis. This is because China is, formally speaking, the largest communist economy-although it

\footnotetext{
${ }^{158}$ It is generally explained that chaebols (large family corporate groups) in Korea and privately owned corporations in China have close connections with the government. See Ronald J. Gilson \& Curtis J. Milhaupt, Economically Benevolent Dictators: Lessons for Developing Democracies, 59 AM. J. CoMP. L. 227, 246 (2011) (“Chaebol structures still reflect their origins in the growth alliance with the [Chung-Hee] Park regime [in Korea]."); Curtis J. Milhaupt \& Wentong Zheng, Beyond Ownership: State Capitalism and the Chinese Firm, 103 GEO. L.J. 665, 669 (2015) ("[L]arge firms in China-whether [stateowned enterprises], [privately owned enterprises], or ambiguous state-private blendssurvive and prosper precisely because they have fostered connections to state power and have succeeded in obtaining state-generated rents.").

${ }^{159}$ In other words, Part IV does not cover Chinese SOEs, which do their main businesses in foreign markets. Accordingly, consumers of SOEs in Part IV are generally the citizens of China. In addition, Part IV analyzes mainly SOEs where the government holds a high percentage of ownership.
} 
adopts many pragmatic market-oriented policies - and SOEs are main business entities in most sectors.

Recently, the significance of Chinese SOEs in the world economy has been evident. "More than half of the Chinese companies in the 2012 Fortune Global 500 are SOEs supervised by an organ of the central government." 160 In many Chinese domestic markets, SOEs play as (quasi) monopolists with strong market power. ${ }^{161}$ In this respect, it is crucial to analyze which effects are expected if SOEs in domestic markets pursue the shareholder wealth maximization norm widely supported by economists, legal scholars, practitioners, and policy-makers in developed economies.

By definition, the government is a controlling shareholder of SOEs. ${ }^{162}$ It is noteworthy, however, that the Chinese government is the "agent" of the citizens of China. ${ }^{163}$ In other words, the Chinese government resembles Janus, with two-faces, one as the principal of SOEs and the other as the agent of the Chinese people. In principle, the citizens of China as a group are the "real principal" and the "ultimate shareholders" 164 of SOEs. Similar analysis can be applied in a context of Chinese SOEs that a local government owns on behalf of the local citizens. In order to maximize the welfare of the "ultimate shareholders," it would be - in appearance - rational for SOEs to pursue the monopoly profit maximization strategy, by charging the high monopoly price (i.e., $\mathrm{Pm}$ ) and producing the low level of quantity (i.e., $Q m$ ).

\footnotetext{
${ }^{160}$ Li-Wen Lin \& Curtis J. Milhaupt, We Are the (National) Champions: Understanding the Mechanisms of State Capitalism in China, 65 STAN. L. REv. 697, 699 (2013) (citing State-Owned Assets Supervision \& Admin. Comm'n of the State Council, Central SOEs, http://www.sasac.gov.cn/n2963340/n2971121/n4956567/4956583.html). "Many other Chinese firms on the Fortune Global 500 are SOEs controlled by provincial or local governments." Id. at 699 n.5.

${ }^{161}$ See China to Push Forward Reform of State-Owned Companies, CCTV (May 9, 2012, 18:58), http://english.cntv.cn/program/newshour/20120509/118402.shtml (explaining briefly monopolistic features of Chinese SOEs and future reforms).

${ }^{162}$ For example, at the central government level the State-Owned Assets Supervision and Administration Commission of the State Council (SASAC), an organ of the party-state, supervises many SOEs. See Lin \& Milhaupt, supra note 160, at 700 (explaining that "[the SASAC] has been described as 'the world's largest controlling shareholder"') (citing Marcos Aguiar et al., SASAC: China's Megashareholder, BCG PERSPECTIVES (Dec. 1, 2007),

http://www.bcgperspectives.com/content/articles/globalization_strategy_sasac_chinas_meg ashareholder).

${ }^{163}$ See Clarke, supra note 32, at 499.

${ }^{164}$ More precisely, the citizens of China are not formally "shareholders" of SOEs. Instead, the controlling shareholder of Chinese SOEs is the government. Accordingly, the citizens of China are "beneficiaries" under the government. Nonetheless, this Article bases its explanations on the notion that the citizens of China are "ultimate shareholders" of SOEs, since such an analysis is functionally correct.
} 
In the above analysis, however, one important point is not taken into account. In general, consumers and shareholders are different groups, even if it is possible that a shareholder group constitutes a subset of consumers. Under this general view, one main issue related to (quasi) monopoly profits is the wealth transfer from a consumer group to a shareholder group. In an imperfectly competitive market, the shareholder group is better off and the consumer group is worse off. ${ }^{165}$ Although the shareholder primacy norm would be counterproductive to social welfare as a whole, at the very least the norm is beneficial to the shareholder group in an industrial organization with monopoly or oligopoly. However, this general analysis is unlikely to apply to (quasi) monopoly SOEs particularly when the government holds $100 \%$ ownership (or a high percentage of ownership). ${ }^{166}$ In such cases, "ultimate shareholders" of SOEs are, roughly speaking, the same as consumers in the domestic market. ${ }^{167}$ For instance, an SOE owned by a local government provides a certain service to local consumers, who are actually "ultimate shareholders" of the SOE.

Under these circumstances, consider the impacts of the shareholder wealth maximization norm - if it is strictly pursued by Chinese SOE managers - on the welfare of the "ultimate shareholders." The norm increases the profits of an SOE, for the benefit of the "ultimate shareholders." On the other hand, the welfare of consumers is hurt by the monopoly profit maximization. Technically speaking, a substantial amount of surplus is transferred from consumers to the "ultimate shareholders." Since two conceptually divided groups are actually one group, the transfer of resources simply takes place from a person's right pocket to the left pocket. One critical problem is that the size of DWLvisually depicted as Harberger's triangle - is enlarged during the course of such a transfer. Consequently, the shareholder wealth maximization norm will result in a net loss to the "ultimate shareholders."

Suppose that "consumer primacy"-rather than shareholder primacy - is pursued as the main policy of SOEs in China. On the one

\footnotetext{
${ }^{165}$ See KrugMan \& WeLLS, supra note 6, at 371.

${ }^{166}$ When the government holds $100 \%$ ownership of an SOE, in theory, the citizens of China as a group holds $100 \%$ ownership via the government.

${ }^{167}$ It is noteworthy, however, that there are SOE cases where "ultimate shareholders" would not be same as "consumers." First, by means of voting leverage devices such as stock pyramiding, it is possible that the government can control an SOE with a fractional ownership (e.g., 25\%). In this example, while the citizens of China (as a group) are "consumers," they account for merely $25 \%$ of "ultimate shareholders." Accordingly, the group of "ultimate shareholders" is a subset of the group of "consumers." Second, suppose that an SOE is run by a local government, but provides goods or services to all citizens of China. Even if the SOE is wholly owned by the local government, two groups would not be same. These situations are beyond the scope of this Article, and will be explored in more depth by my future research projects.
} 
hand, a certain portion of profits - that an SOE could have collected, if the profit maximization strategy had been pursued-for the "ultimate shareholders" would be given up. This portion is obviously a loss (or an opportunity cost) to the citizens of China. On the other hand, as a large consumer group, the citizens of China will benefit from a lower price (which is lower than $P m$ and approaches $P c$ ) and a higher quantity (which is higher than $Q m$ and approaches $Q c$ ). The combined effect is more desirable to the citizens of China. For this reason, given that the current regime of monopolistic SOEs is firmly established in Chinese market and legal systems - thus, impractical to reform on a large scale in the short term-pursuing a policy that is purely in line with the shareholder wealth maximization norm could generate unintended negative consequences.

As discussed, Roe made an argument that the shareholder wealth maximization norm is not fit for a (quasi) monopoly economy, since it reduces national welfare. ${ }^{168} \mathrm{I}$ argue that the shareholder wealth maximization norm is not fit for at least some Chinese SOEs, since it can be harmful to the "ultimate shareholders," not to mention that it risks lowering social welfare. Table 3 summarizes the above analysis. Although Table 3 provides a simplified framework, it is a good start for future research on the welfare of consumers and "ultimate shareholders" of Chinese SOEs. ${ }^{169}$

Table 3: Welfare of Ultimate Shareholders of Chinese SOEs When Profits Are Maximized (Analysis Based on Figure 1)

\begin{tabular}{|c|c|c|}
\hline & $\begin{array}{c}\text { BENEFIT/COST AS } \\
\text { SHAREHOLDERS }\end{array}$ & $\begin{array}{c}\text { BENEFIT/COST AS } \\
\text { CONSUMERS }\end{array}$ \\
\hline $\begin{array}{c}\text { Wealth Transfer -- } \\
- \text { (i) }\end{array}$ & $+\mathrm{A}$ & $-\mathrm{A}$ \\
\hline $\begin{array}{c}\text { Deadweight Loss - } \\
--(\mathrm{ii})\end{array}$ & $-\mathrm{C}$ & $-\mathrm{B}$ \\
\hline (i) + (ii) & {$[+\mathrm{A}-\mathrm{C}]--$ (iii) } & {$[-\mathrm{A}-\mathrm{B}]--$ (iv) } \\
\hline \hline Total Benefit/Cost & \multicolumn{2}{|c|}{$[\mathrm{A}-\mathrm{C}]+[-\mathrm{A}-\mathrm{B}]=[-\mathrm{B}-\mathrm{C}]$} \\
\hline
\end{tabular}

${ }^{168}$ See supra text accompanying note 12.

${ }^{169}$ Note that the underlying assumption of Table 3 is that the "ultimate shareholder" group is roughly same as consumer group. In regard to this assumption, additional issues that will be further analyzed in an independent project are as follows: (1) How are outcomes in Table 3 different, if an SOE has consumers in foreign countries?; (2) How does CMSwhen it dilutes the government's ownership very much - affect the analysis in Table 3?; (3) What if a province government owns an SOE that also has consumers in other provinces?; and (4) How does (and can) an SOE really distribute benefits to its "ultimate shareholders"? 


\section{of Ultimate
Shareholders $[($ iii $)+$ (iv)]}

- Notation (based on supra Figure 1 and supra Part II.B.1)
A: Rectangle $A$
B: Triangle $B$
$\mathrm{C}$ : Triangle $C$
$+:$ Benefit
- : Cost

- Shareholder Group = Consumer Group Thus, under the shareholder wealth maximization norm in a (quasi) monopoly, the total benefit/cost of "ultimate shareholders" is: (iii) $+(\mathrm{iv})=[\mathrm{A}-\mathrm{C}]+[-\mathrm{A}-\mathrm{B}]=[-\mathrm{B}-$ C]. Accordingly, the shareholder wealth maximization norm will result in a net loss to "ultimate shareholders" in Chinese SOEs.

\section{CONCLUSION}

In The Shareholder Wealth Maximization Norm and Industrial Organization, Roe raised a significant and fundamental question, namely, whether the shareholder wealth maximization norm is fit to be the global corporate governance standard in countries dominated by (quasi) monopolies. Despite his huge contribution in this uncharted territory between industrial organization and corporate governance, Roe did not cover important issues such as CMS, tunneling, and the application of shareholder primacy to the Chinese economy and SOEs. Based on Roe's omissions, this Article uses a complex analytical framework to explore the question of (quasi) monopoly, shareholder wealth maximization, investor protection, and national welfare. ${ }^{170}$

When a controller's economic interests in a (quasi) monopoly corporation account for only a small fraction (i.e., a deep CMS), the controller has a weak incentive to follow the profit maximization norm. Under these circumstances, public shareholders would be damaged due to the deviation from the maximized-profit point. However, it is generally expected that consumers and the national economy as a whole would inadvertently - perhaps without the CMS controller's bona fide intentbenefit relative to cases where the shareholder primacy norm is pursued in a strict manner. The lower a CMS controller's ownership stake in a

\footnotetext{
${ }^{170}$ See supra Part III and Part IV.
} 
corporation is, the weaker the incentive to comply with shareholder wealth maximization.

By definition, tunneling is detrimental to public shareholders. An interesting byproduct of tunneling in a (quasi) monopoly CMS corporation is that a CMS controller, ceteris paribus, has an additional incentive to consider a profit maximization strategy (due to a higher level of the CMS controller's economic interests in the corporation) that would be potentially beneficial to public shareholders. Of course, if the negative impact of tunneling on public shareholders overwhelms the positive one, public shareholders would end up with welfare loss. Nonetheless, commentators should recognize - at least at a conceptual level-the potentially positive corporate governance feature of tunneling. In addition, given CMS, tunneling of substantially all corporate assets is the worst scenario in terms of industrial organization, corporate governance (investor protection), and social welfare. ${ }^{171}$

Regarding SOEs in China, the shareholder wealth maximization norm, if it is strictly transplanted, would create unintended negative effects to the economy given legal and market institutions in China which are not easily reformed. Specifically, the norm - which is intended to protect shareholders and make them better off-will, ironically, lower the welfare level of the "ultimate shareholders" in Chinese SOEs, not to mention the detrimental impact of greater monopoly rents on the national economy. $^{172}$

\footnotetext{
${ }^{171}$ See supra Part III.C.1.

${ }^{172}$ See supra Part IV.
} 